\title{
Funerary practices or food delicatessen? Human remains with anthropic marks from the Western Mediterranean Mesolithic
}

\author{
Juan V. Morales-Pérez a,*, Domingo C. Salazar-García ${ }^{\text {a,b,c }}{ }^{\text {, }}$ Mํㄹ Paz de Miguel Ibáñez $^{\text {d }}$, Carles Miret i Estruch ${ }^{\text {, }}$ \\ Jesús F. Jordá Pardo ${ }^{\mathrm{e}}$, C. Carlos Verdasco Cebrián ${ }^{a}$, Manuel Pérez Ripoll a, J. Emili Aura Tortosa ${ }^{a}$ \\ a Departament de Prehistòria, Arqueologia i Història Antiga, Universitat de València, Avda. Blasco Ibañez 28, E-46010 València, Spain \\ ${ }^{\mathrm{b}}$ Department of Archaeology, University of Cape Town, Private Bag X3, Rondebosch 7701, South Africa \\ ' Department of Archaeogenetics, Max Planck Institute for the Science of Human History, Kahlaische Strasse 10, 07743 Jena, Germany \\ ${ }^{\mathrm{d}}$ Departamento de Prehistoria, Arqueología, Historia Antigua, Filología Griega y Filología Latina, Universidad de Alicante, Carretera de Sant Vicent del Raspeig, s/n, \\ E-03690 Sant Vicent del Raspeig, Alicante, Spain \\ ${ }^{\mathrm{e}}$ Laboratorio de Estudios Paleolíticos, Dep. de Prehistoria y Arqueología, Facultad de Geografía e Historia, Universidad Nacional de Educación a Distancia, Paseo Senda del Rey 7 , \\ E-28040 Madrid, Spain
}

\section{A R T I C L E I N F O}

\section{Article history:}

Received 25 April 2016

Revision received 3 November 2016

Accepted 9 November 2016

\section{Keywords:}

Prehistoric cannibalism

Disarticulated human remains

Iberia

Santa Maira

Western Mediterranean Mesolithic

\begin{abstract}
A B S T R A C T
The identification of unarticulated human remains with anthropic marks in archaeological contexts normally involves solving two issues: a general one associated with the analysis and description of the anthropic manipulation marks, and another with regard to the interpretation of their purpose. In this paper we present new evidence of anthropophagic behaviour amongst hunter-gatherer groups of the Mediterranean Mesolithic. A total of 30 human remains with anthropic manipulation marks have been found in the Mesolithic layers of Coves de Santa Maira (Castell de Castells, Alicante, Spain), dating from ca. 10.2-9 cal ky BP. We describe the different marks identified on both human and faunal remains at the site (lithic, tooth, percussion and fire marks on bone cortex). As well as describing these marks, and considering that both human and faunal remains at the site present similar depositional and taphonomic features, this paper also contextualizes them within the archaeological context and subsistence patterns described for Mesolithic groups in the region. We cannot entirely rule out the possibility that these practices may be the result of periodic food stress suffered by the human populations. These anthropophagic events at the site coincide with a cultural change at the regional Epipalaeolithic-Mesolithic transition.
\end{abstract}

(c) 2016 Elsevier Inc. All rights reserved.

\section{Introduction}

The appearance of disarticulated human remains with anthropic manipulation marks is normally linked to anthropophagic behaviours or to ritual processes of defleshing and dismembering (Botella et al., 2000). This topic has been a source of controversial debate for decades in the field of Anthropology (e.g. Arens, 1979; Kolata, 1986; Diamond, 2000; Neufeldt, 2012), and many works have focused on the definition of the diagnostic criteria used to identify this phenomenon (e.g. Boulestin, 1999; Fernández-Jalvo and Andrews, 2011; Marlar et al., 2000; Outram et al., 2005). This interest seems to be associated with the difficulty of identifying these behaviours rather than the fact that they might still be considered taboo in many modern societies (Boulestin, 1999). Many studies have identified the presence of anthropophagic practices in a wide variety of archaeological contexts and periods. This

\footnotetext{
* Corresponding author.

E-mail address: Juan.morales@uv.es (J.V. Morales-Pérez).
}

practice has been described at the Early Pleistocene TD6 level of Gran Dolina (Saladié et al., 2013), among several Neanderthal remains (e.g. Defleur et al., 1993; Rosas et al., 2006), in Upper Palaeolithic (e.g. Bello et al., 2015) and Mesolithic contexts (e.g. Boulestin, 1999; Gray Jones, 2011) in Northern Europe, and in more recent prehistoric times (e.g. Villa, 1992). However, it has not been properly addressed in the prehistory of some regions like the Western Mediterranean.

This is the first study to report and describe a Mesolithic collection of disarticulated human remains with anthropic marks from the Western European Mediterranean Region (WEMR). The collection comes from the archaeological site of Coves de Santa Maira (Alicante, Spain) (Fig. 1A), and is dated to ca. 10.2-9 ky cal BP (Table 1). This archaeological site is located at $600 \mathrm{~m}$ above sea level on the Prebetic Ranges, $120 \mathrm{~km}$ south of the city of Valencia and $30 \mathrm{~km}$ away from the current coastline. The site is divided into two excavated sectors: "West hall" and "Corral" (Fig. 1B). Of these, at present only the former has yielded human remains and is thus the focus of our study. The "West hall" archaeological sequence is 

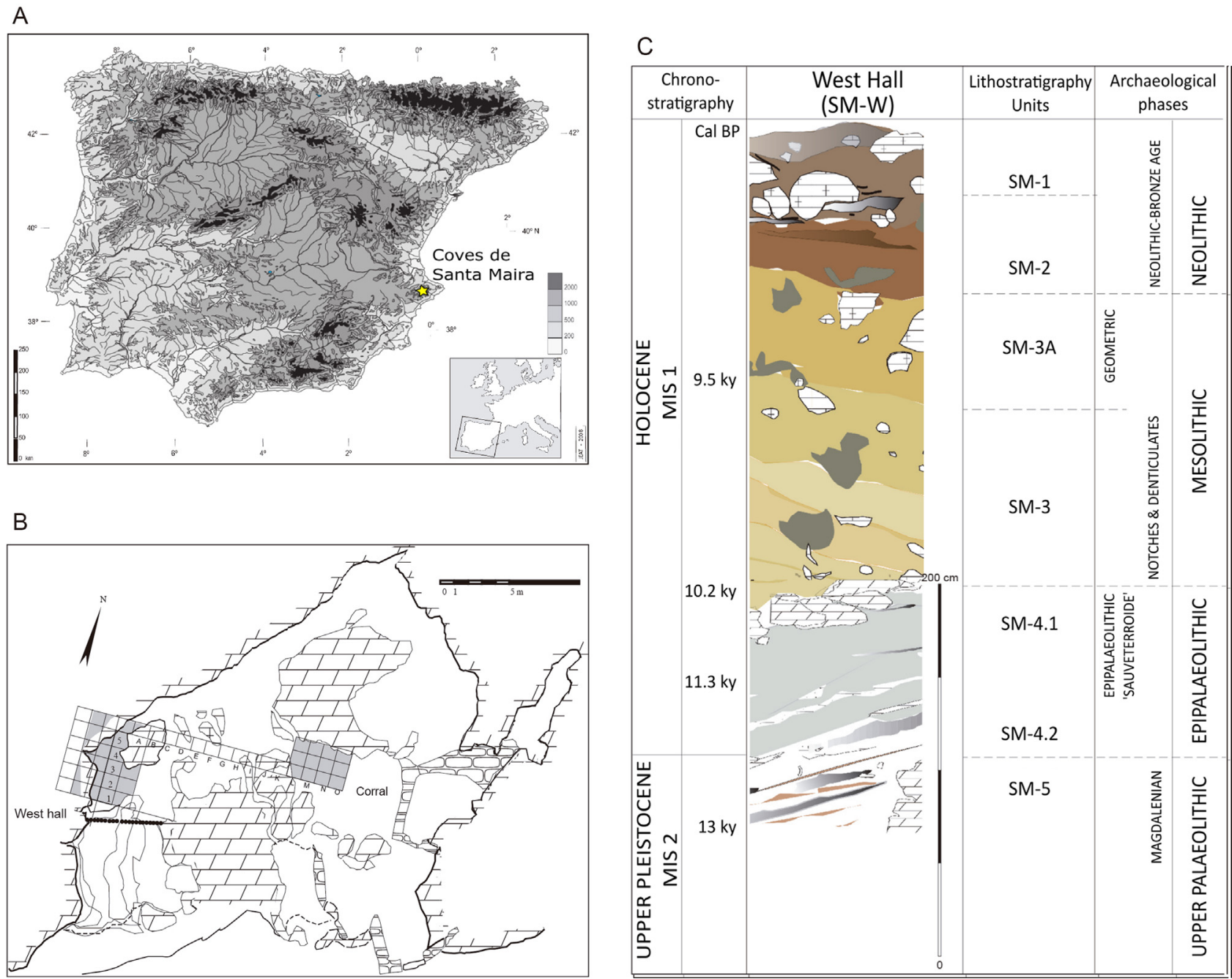

Fig. 1. Location (A), plan (B) and stratigraphy (C) of the archaeological site of Coves de Santa Maira.

Table 1

Radiocarbon dates from level SM-3 of Santa Maira.

\begin{tabular}{|c|c|c|c|c|c|c|c|}
\hline levels & Period & Date BP & cal BP & Sample & Lab. Nr. & Procedure & Ref. \\
\hline $\begin{array}{l}\text { SM-3 } \\
\quad \text { Layer } 3.6\end{array}$ & Mesolithic & $8283 \pm 37$ & $9420-9130$ & $\begin{array}{l}\text { Homo sapiens } \\
\text { (infantile scapula SM-W-HS-14) }\end{array}$ & OxA-V-2360-26 & AMS & Salazar-García et al. (2014) \\
\hline $\begin{array}{l}\text { SM-3 } \\
\quad \text { Layer } 3.18\end{array}$ & Mesolithic & $8690 \pm 50$ & $9725-9583$ & $\begin{array}{l}\text { Homo sapiens } \\
\text { (adult femur shaft fragment SM-W-HS 26) }\end{array}$ & Beta-244010 & AMS & Aura Tortosa et al. (2011) \\
\hline $\begin{array}{l}\text { SM-3 } \\
\quad \text { Layer } 3.21\end{array}$ & Mesolithic & $8890 \pm 50$ & $10134-9926$ & Cervus elaphus & Beta 244011 & AMS & Aura Tortosa et al. (2011) \\
\hline
\end{tabular}

divided into five major lithostratigraphic units with different cultural facies (Fig. 1C): Late Upper Palaeolithic (level SM-5: 15$12.9 \mathrm{ky}$ cal BP), Epipalaeolithic (level SM-4: 12.9-10.2 ky cal BP), Mesolithic (level SM-3: ca. 10.2-9 ky cal BP), Neolithic (level SM-2: 6.6-6 ky cal BP), and later periods (level SM-1: Chalcolithic to Middle Ages). This sequence has enabled us to obtain important data about the chronology, palaeoenvironmental evolution and techno-economic patterns of the hunter-gatherers who occupied it during the Pleistocene-Holocene transition.

All the human remains with anthropogenic marks have appeared at Level SM-3 (Fig. 2). This Mesolithic level was formed over a period of approximately 1000 years and has an uneven thickness $(30-150 \mathrm{~cm})$ with a marked slope towards the interior of the cavity. Its deposit is mostly made up of clay, silt and sand (95\%), and its base is formed by a group of large limestone blocks that separate it from SM-4. Level SM-3 is currently subdivided into 6 subunits and includes bones brought to the site by birds of prey and small carnivores, which suggest short episodes of non-human occupation. It is possible that the mesolithic hunter-gatherers occupied the outer hall of the cave and that the current position of the archaeological deposits might have resulted from gravitational processes (Aura Tortosa et al., 2006). 


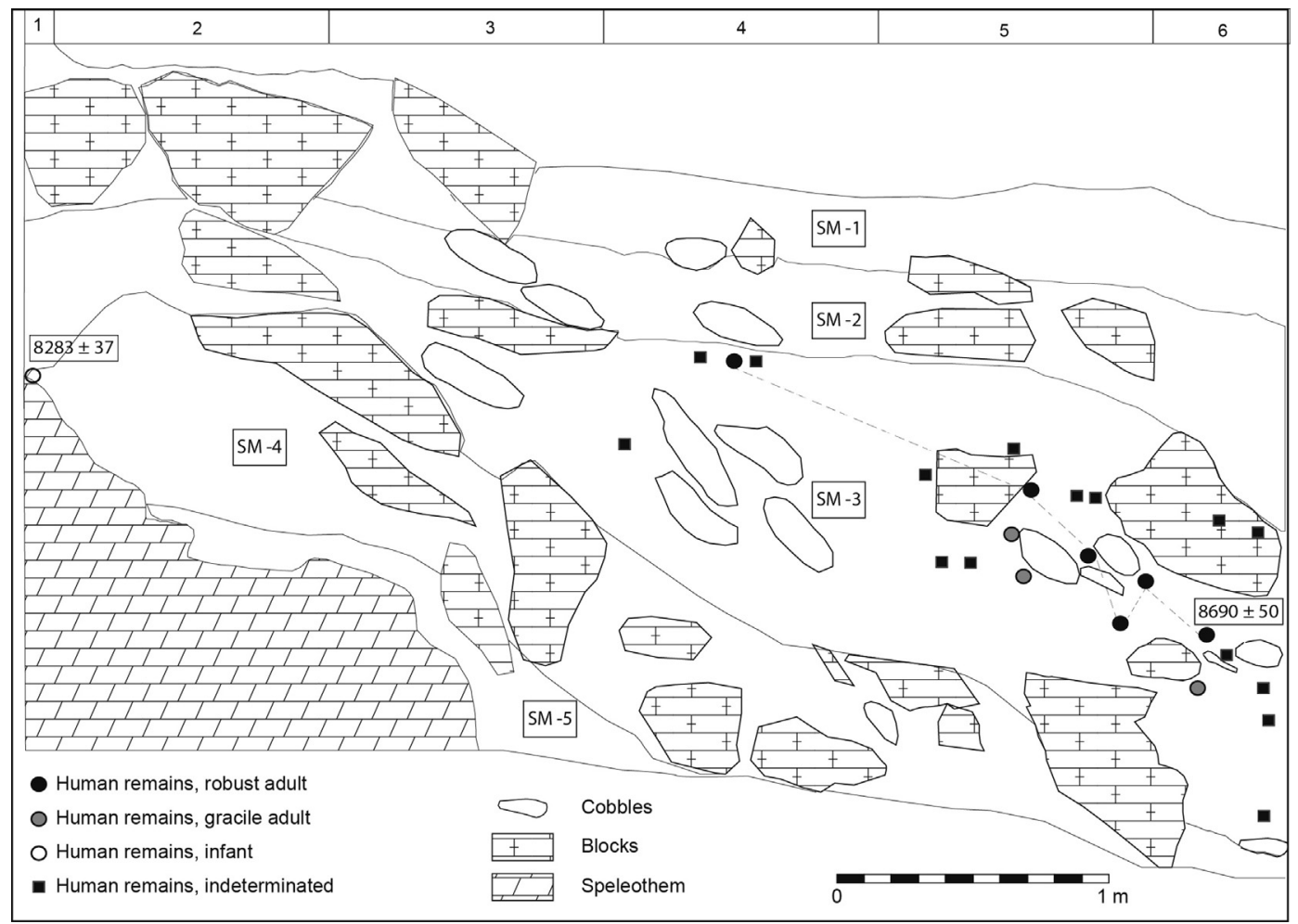

Fig. 2. Stratigraphic situation of the human remains from level SM-3.

\section{Material and methods}

Thirty human remains have been identified so far in the SM-3 level of the "West hall": 26 have clear contexts and 4 are associated with contexts altered by rodent burrowing. These last 4 share common features with the SM-3 remains: (1) they show an excellent state of preservation with no macroscopic alterations caused by weathering or other hydric, chemical or biological agents; (2) they have undergone thermo-alterations; (3) they display similar anthropogenic marks; and (4) their external bone colour is homogeneous. As a result of these criteria, these 4 bones are studied together with the remains clearly recovered from level SM-3 (Table 2).

We have described the different marks identified in this collection by following the same methodology and criteria for both faunal and human remains, studying their morphology and, whenever possible, suggesting the causative agent. Firstly, the study of the anthropogenic marks has taken into account the different types found: lithic, tooth, percussion and fire marks. The purpose behind the marks has also been evaluated: skinning (lithic marks), disarticulating (lithic marks), defleshing (lithic marks, sometimes nibbling), and fracturing to access the bone marrow (percussion points, impact points, anvil or hammer pits, and scratches) or to eat the soft tissues attached to the articulations (flexion or bite marks) (Binford, 1981; Botella, 2005; Botella et al., 2001; Cáceres et al., 2007; Galán et al., 2009; Fernández-Jalvo and Andrews, 2011; Lyman, 1994; Pérez Ripoll, 1992; Saladié et al., 2013; Sharon, 2000; Shipman, 1981; White, 1992).

The physical anthropology study has focused on bone identification, estimation of age, morphological and palaeopathological traits of the bones (Buikstra and Ubelaker, 1994; Capasso et al., 1998; Scheuer and Black, 2000; Ubelaker, 1994) in order to determine the Minimum Number of Individuals (MNI). A total of 19 post-axial, 8 axial and 3 cranial remains have been identified. They establish a MNI of 3 individuals: one robust adult, one gracile adult, and an infant. The infantile individual of \pm 2 years of age is only represented by a complete scapula that does not show anthropogenic marks. Two of these three individuals (the robust adult and the infant) have been directly AMS-dated to the Mesolithic period and are coherent with a third dating performed on an associated red deer bone (Table 1 ).

\section{Results}

Analysis of level SM-3 human remains provided a framework for assessing their origin. Presented below are the results of the taphonomic and anthropogenic manipulation mark study: lithic, tooth, percussion and fire marks. The following description of anthropogenic marks follows the logical order of butchery and consumption processes.

\subsection{Lithic marks}

The lithic cut and scrape marks observed on the bones are related to the processes of disarticulation and defleshing (Table 3).

Disarticulation cut marks: These marks are located on the caudal medial surface of the distal articulation of humerus SM-W-HS 20 (Fig. 3). They appear in two groups: the first is located between the olecranon fossa and the medial epicondyle, and the second between the trochlea and the medial epicondyle. Marks belonging to both groups seem to have been caused by the same cutting movement, although overlapping incisions are more numerous and well-marked in the second group. These marks are probably associated with the cutting of the ulnar collateral ligament of the elbow, the forearm tendons and the articular capsule. The process is similar to the disarticulation processes described at Combe Grenal (Garralda et al., 2003).

Defleshing marks: Defleshing should be understood as the process of removing the muscles and flesh packages from the bones. 
Table 2

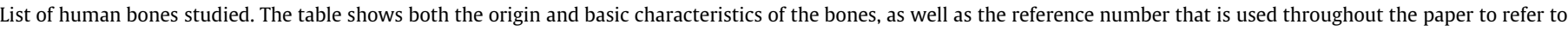
them.

\begin{tabular}{|c|c|c|c|c|c|}
\hline Year & Layer & Sector/square & Bone & Identification & Tables \\
\hline 1983 & III -0.80 & Sector A (ampl) & Calcaneus & $S M-W-H S 1$ & 6 \\
\hline 1996 & $\mathrm{R}$ & C D & First right rib body fragment & $S M-W-H S 3$ & 4,6 \\
\hline 1996 & $\mathrm{R}$ & C D & Rib caudal fragment & $S M-W-H S 4$ & 6 \\
\hline 1996 & $\mathrm{R}$ & CD & Femur or tibia shaft fragment & SM-W-HS 5 & 4,6 \\
\hline 1996 & $\mathrm{R}$ & AA 2 & Shaft fragment (prob. femur) & SM-W-HS 10 & 3 \\
\hline 1996 & 3.1 & $\mathrm{AB} 4 \mathrm{EST}$ & Right rib body fragment & $S M-W-H S 11$ & 3,4 \\
\hline 1996 & 3.1 & $\mathrm{AB} 4 \mathrm{EST}$ & Femur or tibia shaft fragment & SM-W-HS 12 & $3,4,6$ \\
\hline 1997 & 3.1 & $\mathrm{AB} 3 / 7$ & Tibia shaft fragment & SM-W-HS 13 & 5 \\
\hline 1998 & 3.6 & $\mathrm{AA} 2 / 1$ & Infantile scapula & SM-W-HS 14 & \\
\hline 1999 & 3.16 & $\mathrm{AA} 3 / 3$ & Iliac or scapular spine fragment & SM-W-HS 16 & \\
\hline 2000 & 3.5 & AA $5 / 2$ & Skull fragment (parietal + frontal) & $S M-W-H S 17$ & 3,6 \\
\hline 2000 & 3.7 & AA $5 / 1$ & Femur shaft fragment & SM-W-HS 18 & 4 \\
\hline 2000 & & AA $5 / 2$ & Femur shaft fragment & SM-W-HS 19 & $3,4,6$ \\
\hline 2000 & 3.11 & AA $5 / 1$ & Distal humerus & $S M-W-H S 20$ & 3,6 \\
\hline 2000 & 3.13 & AA $5 / 1$ & Shaft fragment & $S M-W-H S 21$ & 6 \\
\hline 2000 & 3.15 & AA $5 / 2$ & Second rib fragment (gracile) & $S M-W-H S 22$ & \\
\hline 2000 & & AA $5 / 2$ & Iliac fragment & $S M-W-H S 23$ & 4 \\
\hline 2000 & & AA $5 / 3$ & Femur shaft fragment & $S M-W-H S 24$ & $3,5,6$ \\
\hline 2000 & & AA 5/4 CAU & Prob. pelvic fragment & $S M-W-H S 25$ & 6 \\
\hline 2000 & 3.18 & $\mathrm{AB} 6 / 1$ & Femur shaft fragment & $S M-W-H S 26$ & $3,5,6$ \\
\hline 2002 & 3.15 & AA $5 / 3$ & Femur shaft fragment & $S M-W-H S 27$ & 6 \\
\hline 2004 & 3.9 & $\mathrm{AB} 5 / 4$ & Tibia shaft fragment & $S M-W-H S 29$ & 4 \\
\hline 2004 & & $\mathrm{AB} 6 / 2$ & Shaft fragment (radius, ulna or fibula) & $S M-W-H S 30$ & 6 \\
\hline 2004 & 3.10 & $\mathrm{AB} 6 / 1$ & Thoracic vertebra (inf. art. proc. frag.) & $S M-W-H S 31$ & 6 \\
\hline 2004 & & $\mathrm{AB} 5 / 3$ & Right upper central incisive & $S M-W-H S 32$ & \\
\hline 2004 & 3.19 & $\mathrm{AB} 6 / 1$ & Tooth fragment & SM-W-HS 33 & \\
\hline 2004 & 3.21 & AA $6 / 1$ & Humerus shaft fragment & $S M-W-H S 34$ & $3,5,6$ \\
\hline 2004 & & $\mathrm{AB} 6 / 2$ & Femur shaft fragment & $S M-W-H S 35$ & 6 \\
\hline 2004 & 3.24 & $\mathrm{AB} 6 / 3$ & Femur shaft fragment & $S M-W-H S 36$ & 6 \\
\hline 2007 & 3.30 & $\mathrm{AB} 6 / 2$ & Distal femur fragment & $S M-W-H S 37$ & 6 \\
\hline
\end{tabular}

Table 3

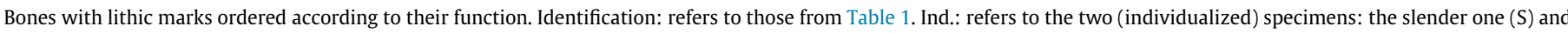

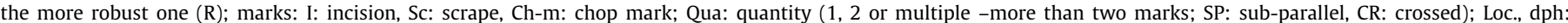

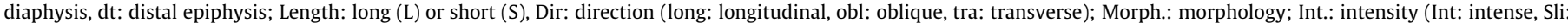
slight); Function: disarticulation (DRT), defleshing (DFL).

\begin{tabular}{|c|c|c|c|c|c|c|c|c|c|c|}
\hline Identification & Ind. & Marks & Qua. & Loc. & Length & Dir. & Morph. & Int. & Function & Fig. \\
\hline SM-W-HS-20 & $S$ & I & Mult SP & $\mathrm{dt}$ & L-S & Long & Fine & Int & DRT & 3 \\
\hline SM-W-HS-10 & $\mathrm{R}$ & I & Mult SP & $\mathrm{dph}$ & $\mathrm{S}$ & Obl & Fine & Int & DFL & 4 \\
\hline SM-W-HS-11 & $\mathrm{R}$ & I & 1 & - & $\mathrm{S}$ & Obl & Fine & Int & DFL & 5 \\
\hline SM-W-HS-12 & $?$ & I & Mult SP & $\mathrm{dph}$ & $\mathrm{S}$ & Obl & Fine & Sli & DFL & 6 \\
\hline SM-W-HS-19 & $\mathrm{R}$ & Sc & $2 \mathrm{CR}$ & dph & $\mathrm{L}$ & Obl & Fine & Int & DFL & 7 \\
\hline SM-W-HS-24 & $\mathrm{R}$ & I & 1 & $\mathrm{dph}$ & $\mathrm{L}$ & Obl & Fine & Int & DFL & 8 \\
\hline SM-W-HS-26 & $\mathrm{R}$ & I & Mult SP & dph & $\mathrm{L}$ & Obl & Fine & Int & DFL & 9 \\
\hline SM-W-HS-34 & $S$ & I & $2 \mathrm{SP}$ & dph & $\mathrm{L}$ & Long & Fine & Sli & DFL & 10 \\
\hline SM-W-HS-17 & $?$ & Ch-m & $2 \mathrm{SP}$ & - & $\mathrm{S}$ & Obl & Flat & Int & DFL & 11 \\
\hline
\end{tabular}

These kinds of lithic marks have been identified in six bone shaft fragments and a cranial fragment (Table 3). The marks appear as a group of sub-parallel incisions in three cases (Figs. 4, 5a and 6), as crossed thin scrape marks in two cases (Figs. 7a and 8a), and as a single incision in one case (Fig. 9). Another single incision occurs in a rib fragment (Fig. 10a). The cranial fragment SM-W-HS 17 shows two large and intense slightly curved scrapes that originate on the upper part, where the scrapes are wider, and continue downwards (Fig. 11). These cranial marks were probably caused by a slight tangential percussion related to the removal of the temporal muscle (they are well-situated on the temporal line) and could therefore be related to the excarnation or cleaning of the cranium.

\subsection{Tooth marks}

The correct identification of tooth marks on human bones is one of the clearest pieces of evidence that a particular body was subjected to cannibalism (Botella et al., 2001; Boulestin, 1999; White, 1992).
However, it is at the same time one of the most complex pieces of taphonomic evidence in terms of its identification and it can be controversial, so it is therefore worth discussing in depth. Because of their ability to severely modify bones, human bite marks can be confused with marks made by other carnivores (Binford, 1981; Brain, 1981; Gifford-Gonzalez, 1989; Landt, 2004; Oliver, 1993), and it is indeed true that distinguishing bite marks made by different carnivores and omnivores - including humans - is a complicated task. However, when the marks result from human biting and gnawing, the intensity of the bite is normally lower and there are no scratches or pit marks, while bones affected by carnivores present clear, intensive tooth marks (e.g. Blasco and Rosell, 2009; Campmas and Beauval, 2008; Delaney-Rivera et al., 2009; Domínguez-Rodrigo and Piqueras, 2003; Haynes, 1980; Pérez Ripoll, 1992; Sauqué et al., 2014; Young et al., 2015). Some recent studies have defined the main traits that almost exclusively characterize bones chewed by humans: double arch punctures in crenulated edges or chewed ends, isolated triangular pits, or shallow linear marks associated with crescent pits (FernándezJalvo and Andrews, 2011; Saladié et al., 2013). In an experimental 


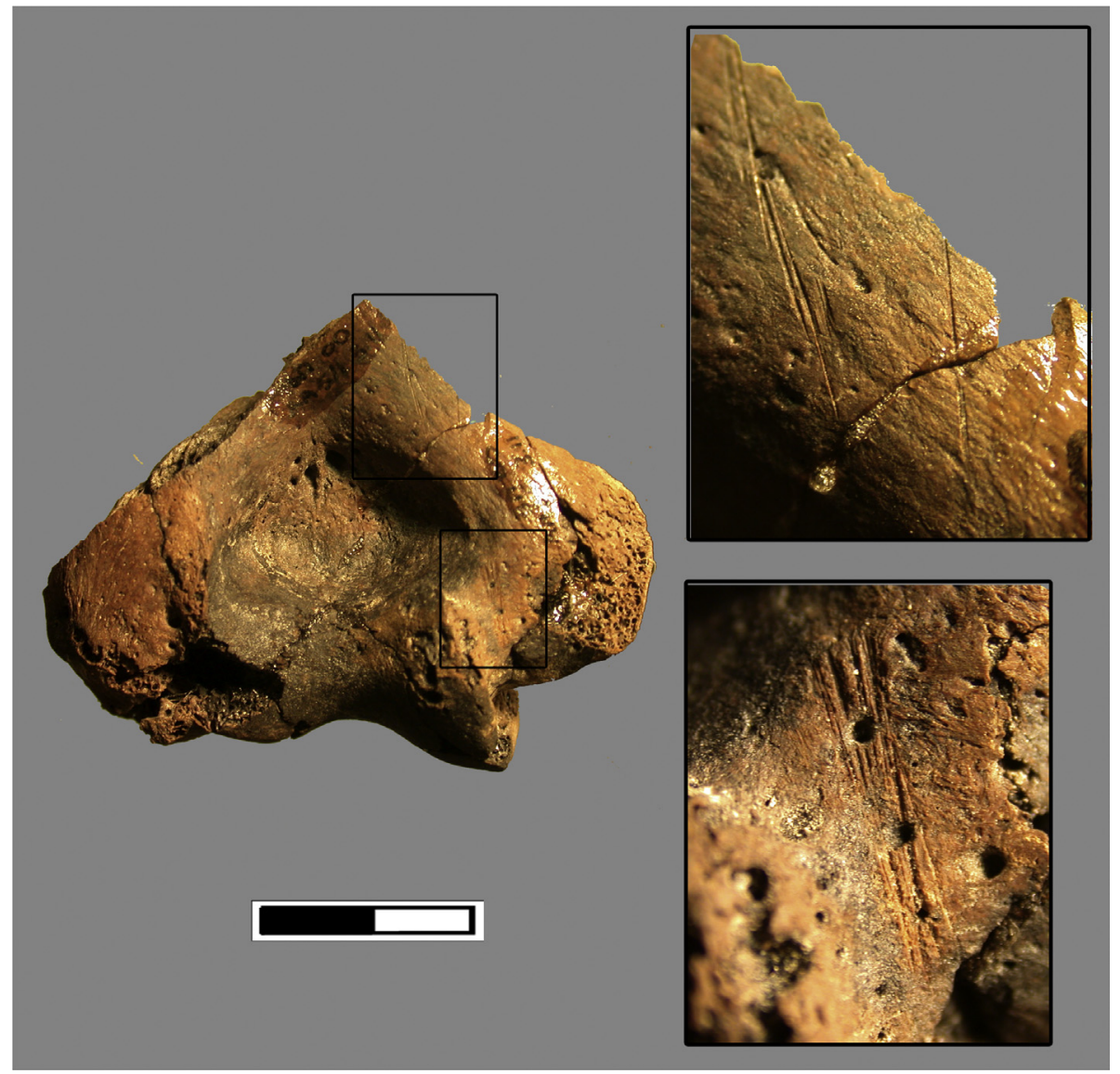

Fig. 3. Distal humerus SM-W-HS 20 with disarticulation cut marks. Caudal view.

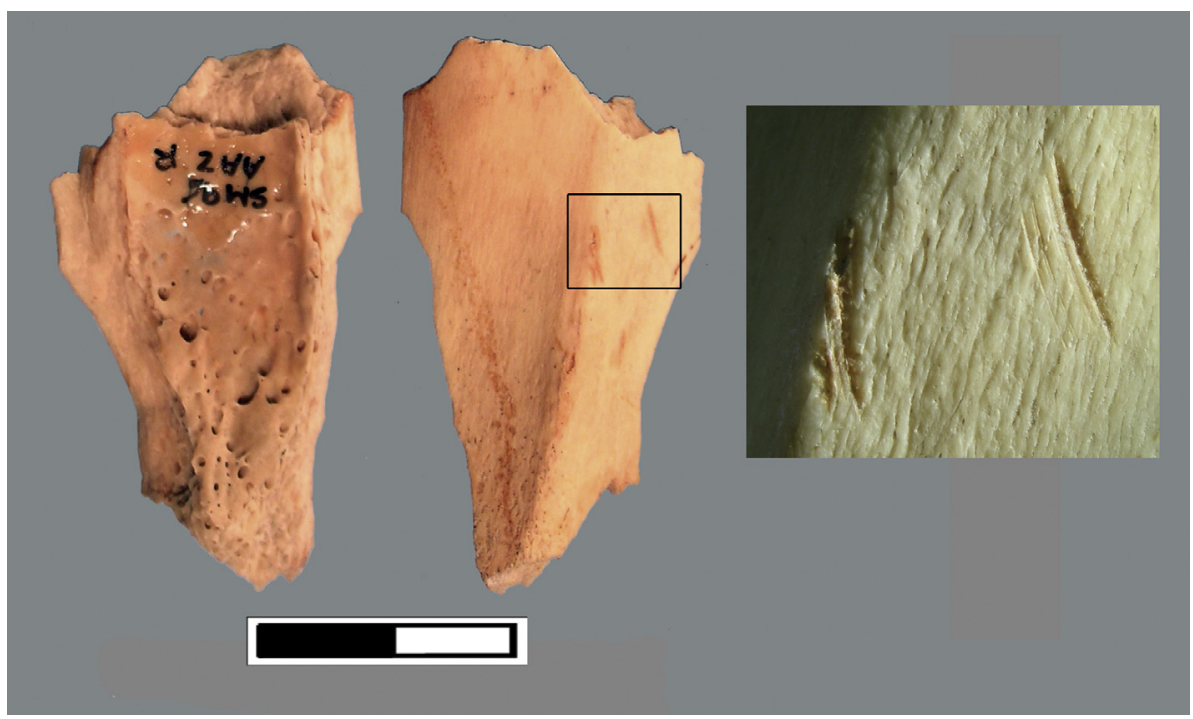

Fig. 4. Shaft fragment SM-W-HS 10 with sub-parallel lithic incisions.

study of human marks on rabbit bones we established the presence of some marks that are similar to those described in this paper. Bearing in mind the differences, it could be seen that there were puncture marks and scrapes on the cortical surface of the long bones due to intensive removal of soft tissue and a number of marks typical of fractures caused by human biting that are similar to those described for the remains found at Santa Maira (Sanchis et al., 2011) and that differ from those made by other predators in terms of the intensity and quantity of marks (e.g. Cochard, 2004; Krajcarz and Krajcarz, 2014; Lloveras et al., 2012; Rodríguez-Hidalgo et al., 2013; Sanchis and Pascual, 2011).

In addition to the above-described criteria, in the case of Santa Maira the small quantity of marks made by carnivores on the bone collection (1.4\% of all the faunal remains identified, Morales Pérez, 2015) makes their anthropic origin even more plausible. 


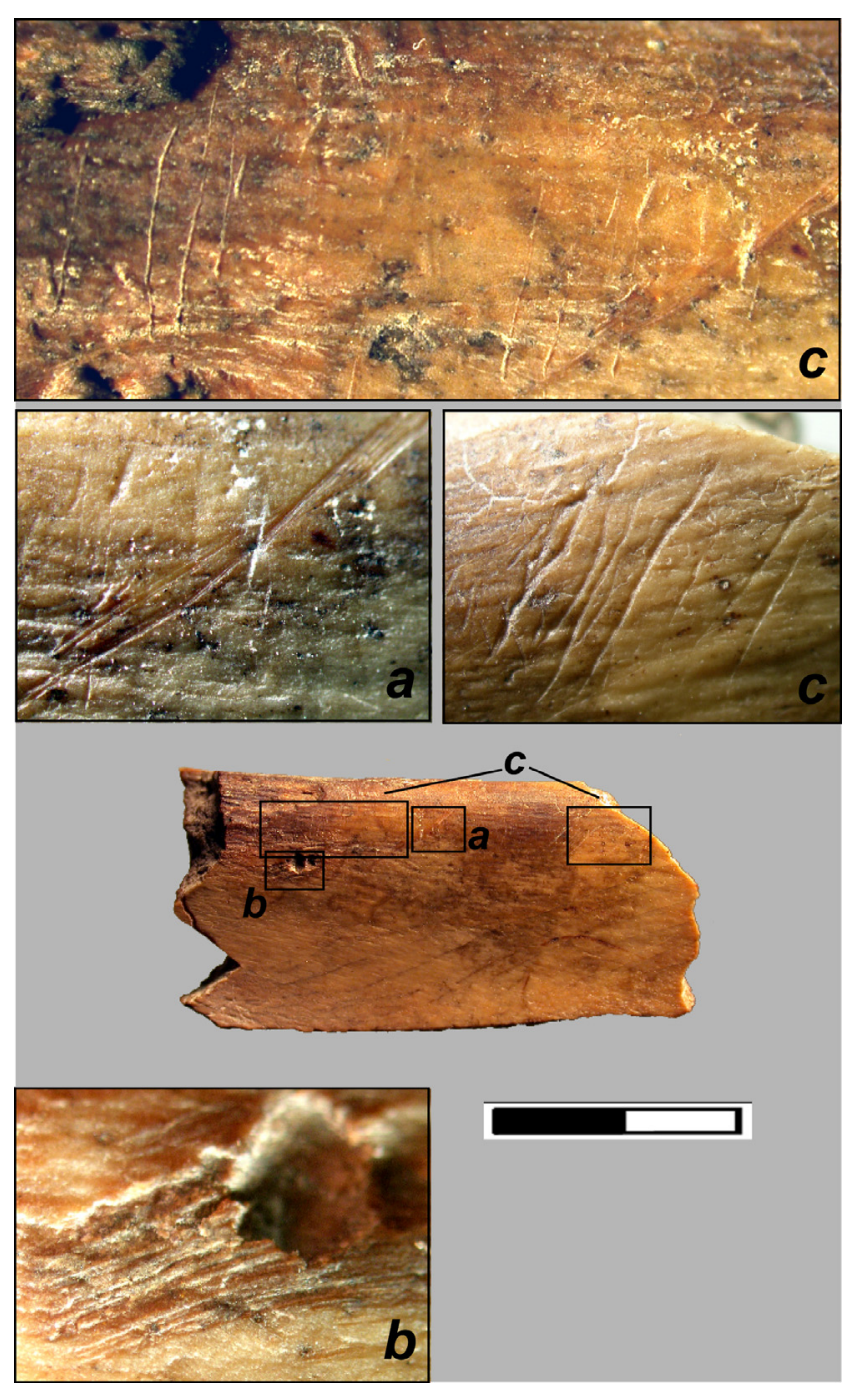

Fig. 5. Shaft fragment SM-W-HS 12 with several anthropic marks: sub-parallel lithic cut-marks (a), an intense flat scrape probably caused by human tooth associated with two pits of uncertain origin (b), and light scores that could be due to human tooth action, but its origin is not known for certain (c).

The marks identified at Santa Maira have been divided into two groups (Table 4).

Defleshing and cleaning tooth marks: These are marks made during the removal and consumption of meat and soft tissues using the teeth, so they tend to be located in areas from which flesh can be taken, and they result from its intensity (there must be very intensive removal of these tissues for the teeth to affect the bone). These are the most difficult marks to identify clearly because of their subtlety and location, and both the causative agent and the fact that they result from dental action could be questioned. However, marks have been identified on the human remains studied here that we attribute, with varying degrees of certainty, to human dental action because they are similar to marks that are considered as such by the aforementioned authors. Moreover, in two cases these marks appear on remains that have other clear anthropic marks.

The femur shaft fragment SM-W-HS 18 presents two pits (triangular-shaped pit, $2.24 \times 1.23 \mathrm{~mm}$; sub-rectangular-shaped pit, $1.35 \times 1.68 \mathrm{~mm}$ ) on the bone surface at the insertion of the vastus medialis muscle (Fig. 12). The morphology and arrangement of these pits suggest that they may have been made by a premolar or molar (Figs. 13 and 14). Due to the shape of the bone, teeth might slip while biting and scrape the bone surface as a result, as suggested by the two shallow scrapes associated with these pits (mean width $=0.93 \mathrm{~mm}$ ). Neither the punctures nor the scores were made by lithic tools, and their morphology and shallowness are also completely different from those produced by carnivore activity. Overall, the bone surface is very well preserved and the fracture seems fresh, without any carnivore chewing marks. This supports an anthropogenic origin of the tooth marks, suggesting they were made during human consumption of the flesh and soft tissues. Similar marks have been detected in shaft fragments of a tibia (Fig. 15), a femur (Fig. 7b1) and a femur or tibia (Fig. 16).

The first of these femur shaft fragments (Fig. 7) also presents other marks, probably associated with the action of human biting, but different from those described above. These marks appear as a crescent pit with flat scores (Fig. 7b1), an isolated crescent pit (Fig. 7b2), a sub-rectangular pit overlapping shallow wide scores (Fig. 7b3), an elongated pit (Fig. 7b2), and isolated wide linear marks with shallow scores (Fig. 7b4). Still referring to the same femoral shaft fragment (Fig. 7b3), as well as the femoral or tibial shaft fragment SM-W-HS 12 (Fig. 5b), another kind of mark is observed: both bones show shallow linear marks similar to those described above and associated with pits. However, in these cases the pits are set on top of the scrapes, cutting through them. This suggests that the scrapes were made prior to the pits, not as a result of the displacement of the tooth after the pressure that created the pit, and unlike the marks described above. The pits in the two previous cases are of uncertain origin, since they are not clearly associated with the scrapes. Furthermore, bone fragment SM-W-HS 12 presents another group of long, irregular, flat, nonlithic marks of unclear origin that could be shallow tooth scores (Fig. 5c).

On the rib fragment SM-W-HS 11 there are some shallow elongated sub-rectangular pits on the intercostal caudal edge that seem to be similar to those described by Cáceres et al. (2007), and which are accompanied by smaller scores surrounding the edge (Fig. 17). The width of the marks is variable $(\min =1.15 ; \max =3.96$; mean $=2.13 \pm 1.08 \mathrm{~mm}$ ). Finally, the external surface of the pelvic bone SM-W-HS 23, next to the greater sciatic notch, shows a series of flat wide scrape marks that could have been caused by the cleaning of the periosteum or by the removal of the gluteus muscle (Fig. 18). These marks are between 0.85 and $1.37 \mathrm{~mm}$ wide.

Bite fractures: These marks have been described in detail in the aforementioned works. As with the previous marks, there is some degree of uncertainty, but these are more clearly anthropic, as similar attacks by carnivores tend to be less selective in terms of the areas chosen and are more destructive. In the case of the rib SM-W-HS 11, a lithic mark has been identified on the same remains. Two different types of bite fracture have been identified in two ribs (Table 4). These fractures differ depending on the morphology and density of the bone that was bitten in each case.

The first type of fracture is a bite fracture on the proximal end of indeterminate rib SM-W-HS 11 (Fig. 5), where a pair of opposed notches can be observed. The notches are conchoidal fractures, wider on the internal part of the bone. Their positions match those of the teeth that could have exerted pressure on the bone and caused it to collapse. Around the notches and the edge of the fracture there are several clearly arranged series of very slight scratches and pits that were probably caused by dental action. The punctual loading point (the two notches), as well as the lightness of the related scratches, seems to imply a human-like action rather than that of a carnivore, which would have been more severe and damaging to the bone. Furthermore, this latter type of fracture is also present amongst human-consumed medium-sized herbivore ribs on the site (Fig. 19).

The second type of fracture has been observed on one first right rib (SM-W-HS 3, Fig. 20). The ends of the rib have been chewed, 

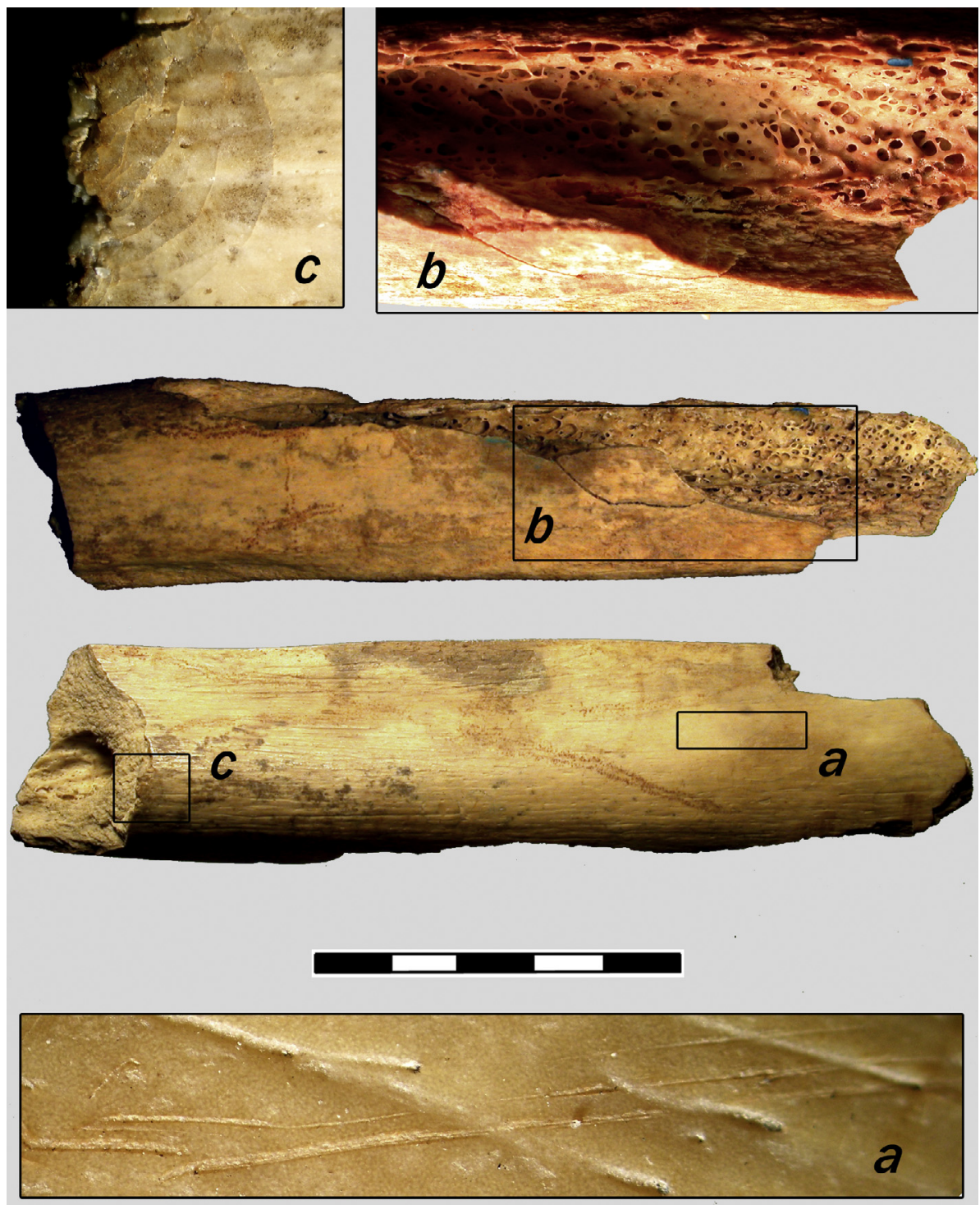

Fig. 6. Femur shaft fragment SM-W-HS 26. In detail: lithic incisions (a), a conchoidal flake still jointed to the shaft in an impact point (b), and a small impact point (c).

creating serrated edges that have been described as crushed and frayed edges (Botella et al., 2001) or as crenulated edges (Fernández-Jalvo and Andrews, 2011; Pickering and Wallis, 1997). The occurrence of these crushed edges is due to the thinner cortex and spongier morphology of this rib, which is less dense than other ribs. The frayed and peeled edges must have been caused by chewing, combined with the pulling and bending of the rib, as has also been described elsewhere for chimpanzees and humans (Cáceres et al., 2007; Fernández-Jalvo and Andrews, 2011; Pickering and Wallis, 1997; Pobiner et al., 2007; White, 1992). The crenulations differ in width from 0.36 to $1.58 \mathrm{~mm}$ and are associated with shallow punctures and pits (ranging from 0.1 to $0.42 \mathrm{~mm}$ ).

\subsection{Percussion or hammering marks}

This is one of the most common ways for bones to be fractured and opened up. In four bone shaft fragments the direct fracture mark, direct impact or loading point appears as a notch and negative flake scars (Table 5), and their percussion pits could be related to the fracturing process itself. There are also at least 12 other bones with fresh fractures similar to those described by Botella et al. (2000), Boulestin (1999), and Villa and Mahieu (1991). This brings the total number of fresh-fractured bones found at the site up to 16.

Three direct impacts can be observed in the shaft fragment SM-W-HS 13. Two of them are accompanied by light, wide scrapes that were probably caused by the friction of the hammer against the bone cortex next to the loading point. These marks can only be observed using a binocular microscope (Fig. 21). In the femur shaft fragment SM-W-HS 26, two different loading points have been observed. The largest is well defined by the extraction of several conchoidal flakes (Fig. 6b); the other is a small impact point with surrounding concentric cracks that might have been caused by the direct impact or by the anvil (Fig. 6c). The slight scrapes described in SM-W-HS 13 can be observed again in SM-W-HS 26. The femur shaft fragment SM-W-HS 24 shows an impact that caused the extraction of a flake from the external bone cortex, probably due to an unsuccessful attempt to fracture the bone (Fig. 9). The humerus shaft fragment SM-W-HS 34 has a loading point that is well defined by the negative flake (Fig. 8b). 

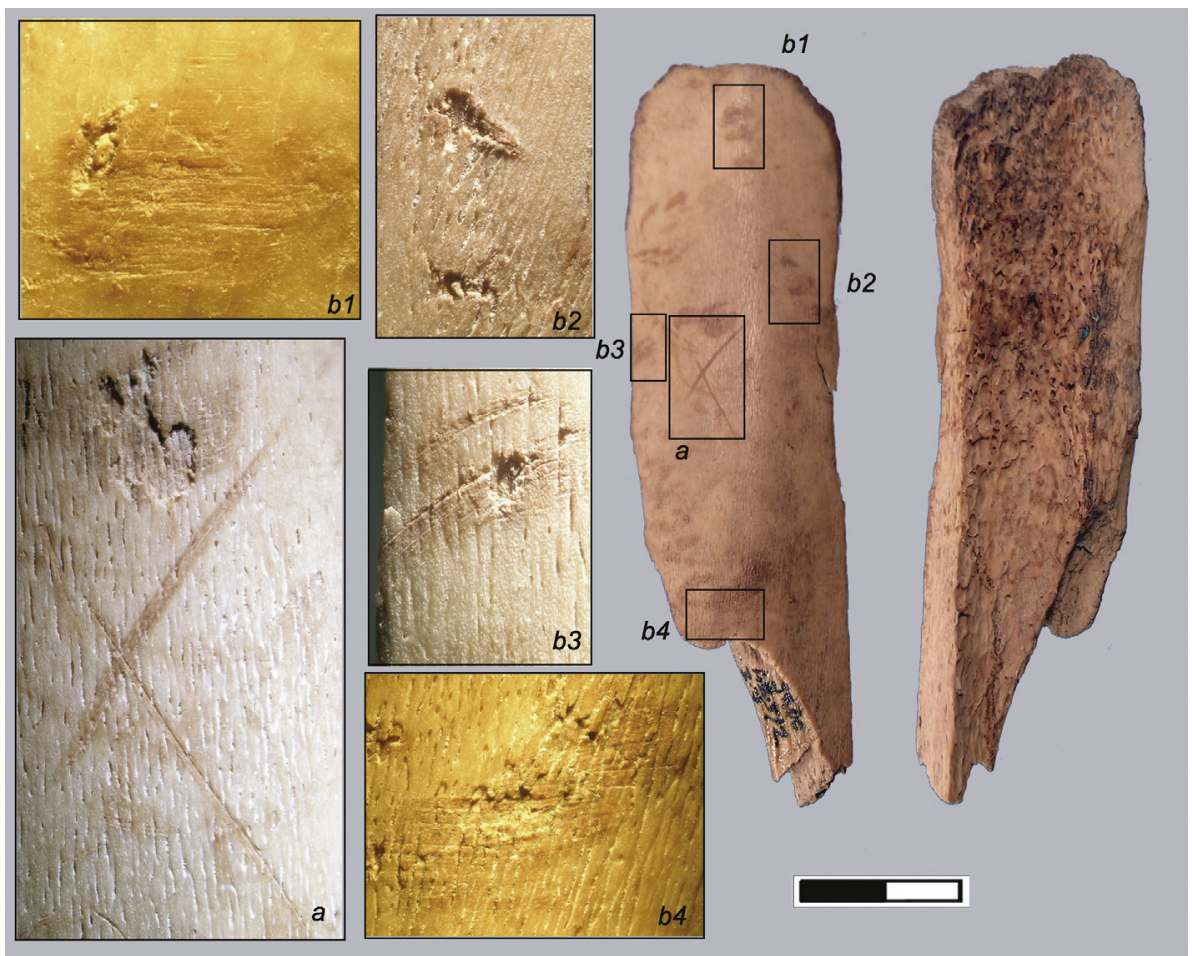

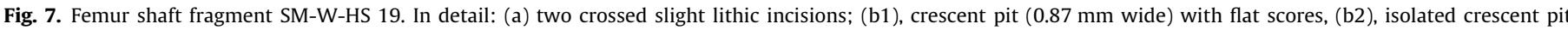
(1.12 mm wide); (b3) sub-rectangular pit overlapping shallow wide scores; (b4) and isolated wide linear marks and shallow scores.

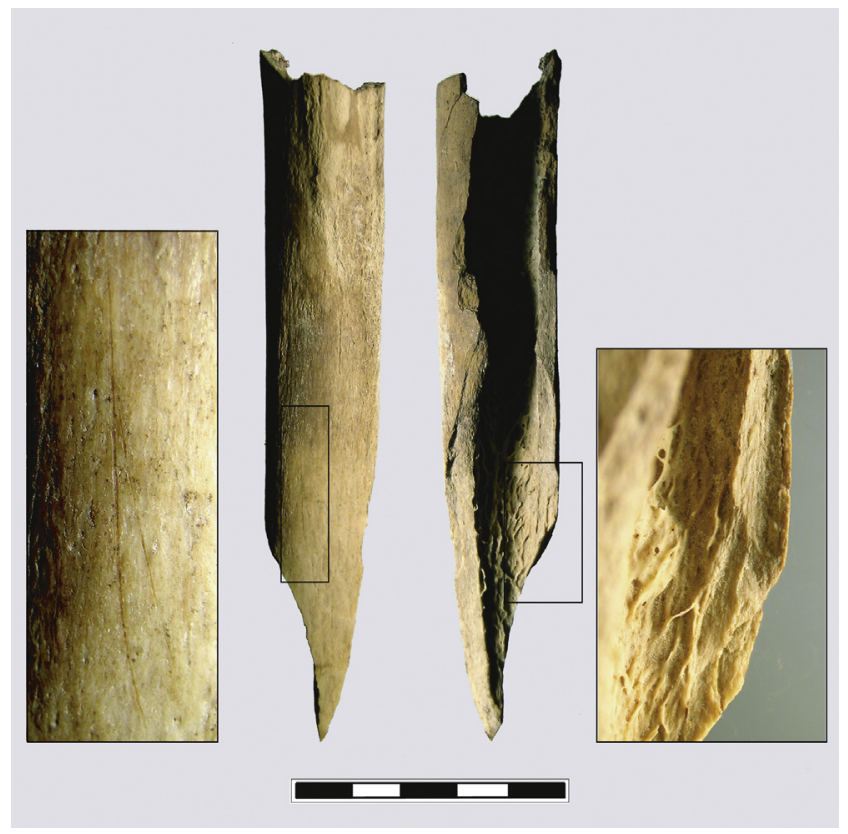

Fig. 8. Humerus shaft fragment SM-W-HS 34. In detail, lithic incisions on the cortex (left, cortical view) and a direct impact (right, internal view).

\subsection{Fire marks}

Thermo-alterations, or fire marks, can either occur during the butchery and consumption processes or by accident. Fire marks have been clearly observed in 19 of the studied remains (Table 6). In another four cases, the bone fragments present a brown colouration that could be due to sediment or other post-depositional agents. These latter remains are not discussed here. The collection of burnt bones includes cranial bones $(\mathrm{NR}=1)$, axial bones $(\mathrm{NR}=3)$ and appendicular bone fragments $(\mathrm{NR}=15)$. The observed fire marks are not very intense, the darkest one reaching a dark brown-black colouring without being carbonized. The majority of the bone fragments show not very intense brown fire marks, which cover the bone partially or completely.

Most bone fragments are burnt along the entirety of their exposed surface, on both the internal and external surfaces, as well as on the fracture edges. These marks occurred after the bone was broken, suggesting that the majority of thermo-alterations were accidental. However, there is a collection of five shaft fragments (Table 6) that are only burnt on their external cortex, but not on their internal surfaces nor on the fresh fracture edges (Fig. 9). Three of these shaft fragments have been identified as femora, and the other two as either tibiae or femora. In all these cases the thermo-alterations seem intentional, resulting from the butchering process. The characteristics of these intentional thermo-alterations on shaft fragments provide information about the overall food processing sequence, since the application of fire to the bone occurred after the meat was removed but before it was fractured.

\section{Discussion}

More than a century after the pioneering studies that focused on the recognition of cannibal practices within the archaeological record (e.g. Garrigou, 1870; Regnault, 1869), the identification of anthropophagous behaviours is mainly based on four points: the butchery process (cut marks, fractures and other related marks), the preparation of the meal (mainly through exposure to fire), the disposal of bones, and the degree of similarity that can be established between human and animal remains (e.g. Villa, 1992; Boulestin et al., 2009; Cáceres et al., 2007; Carbonell et al., 2010; Defleur et al., 1993; Fernández-Jalvo et al., 1999). Boulestin (1999) proposed the following ranking of diagnostic indicators: 


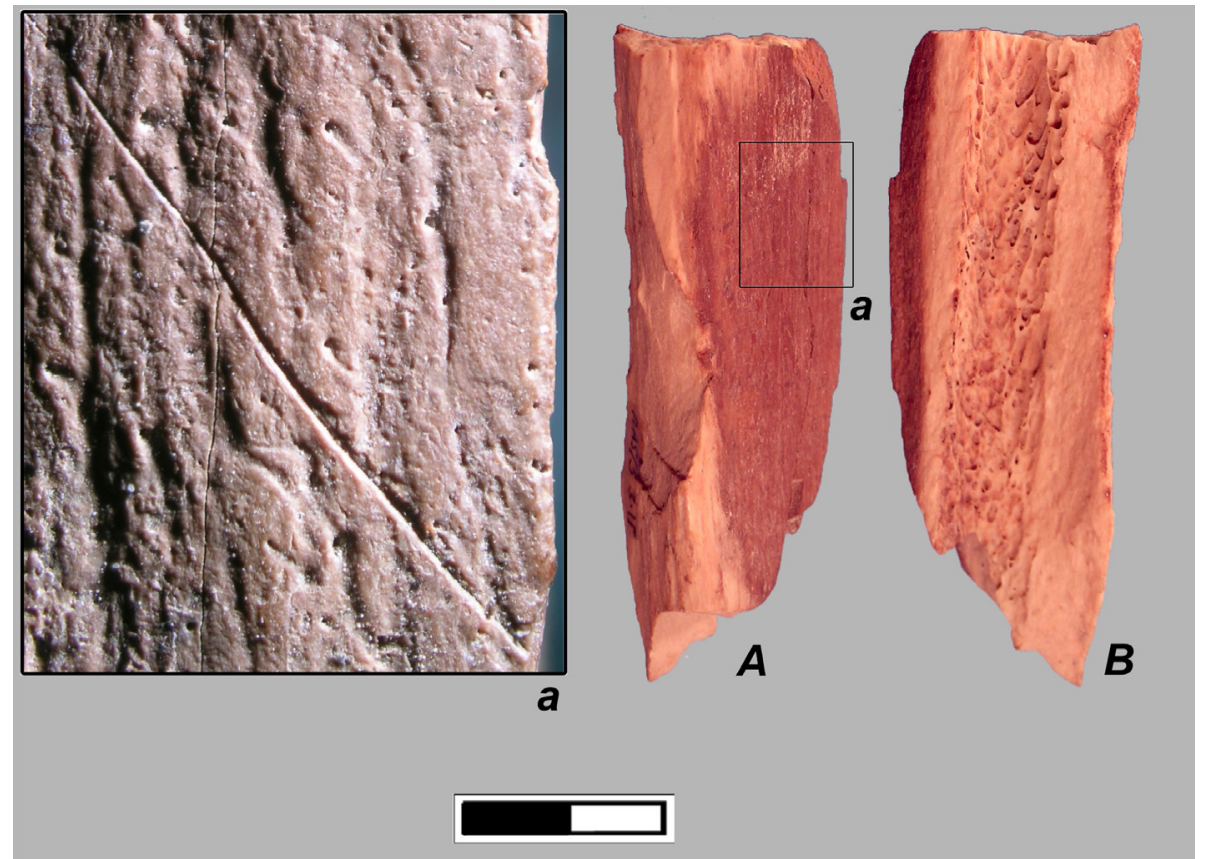

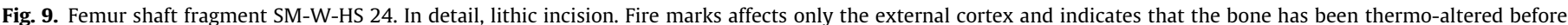
breakage.

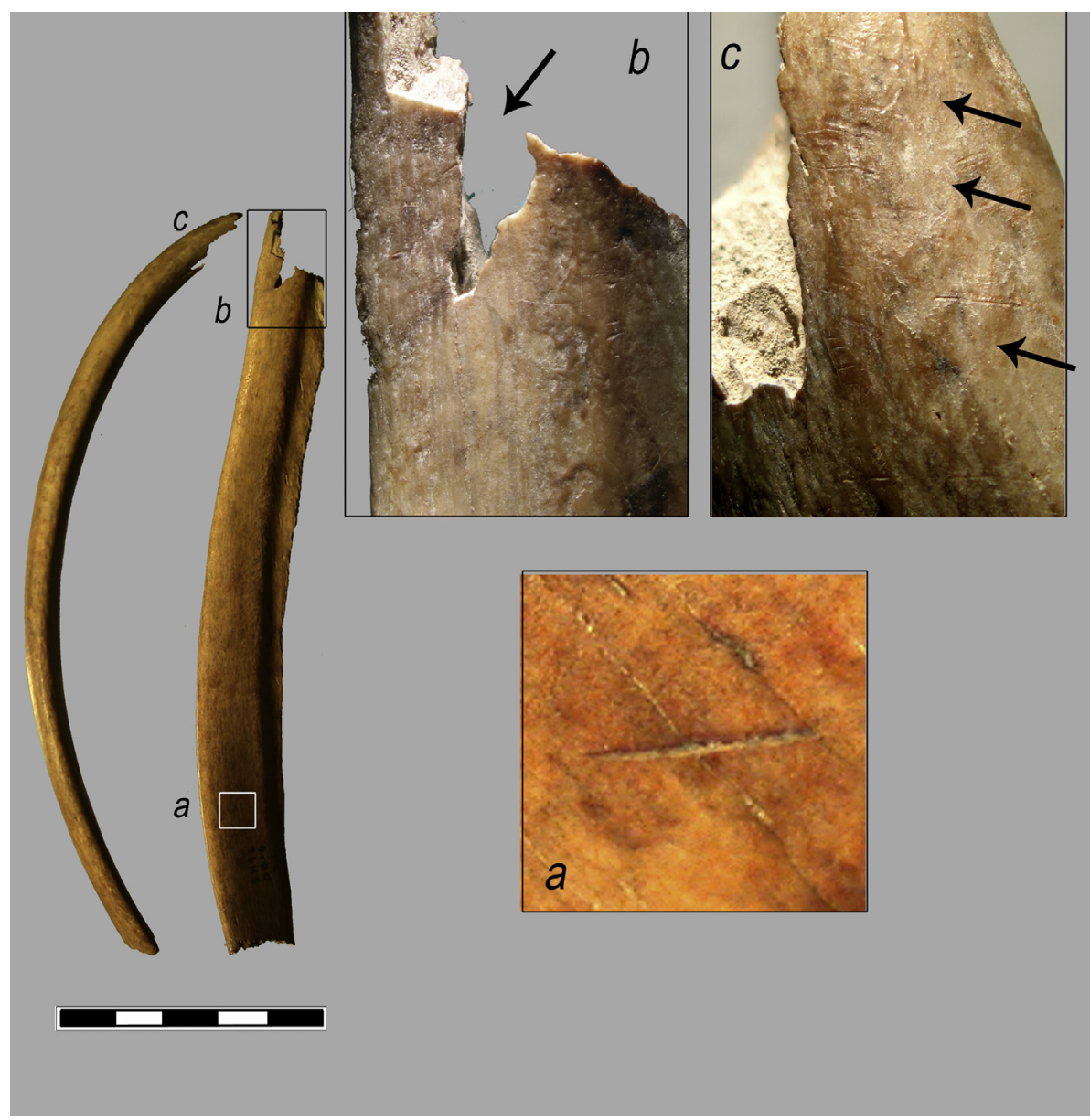

Fig. 10. Rib fragment SM-W-HS 11 with a single transversal lithic incision (a), notches (b), and scores (c). 


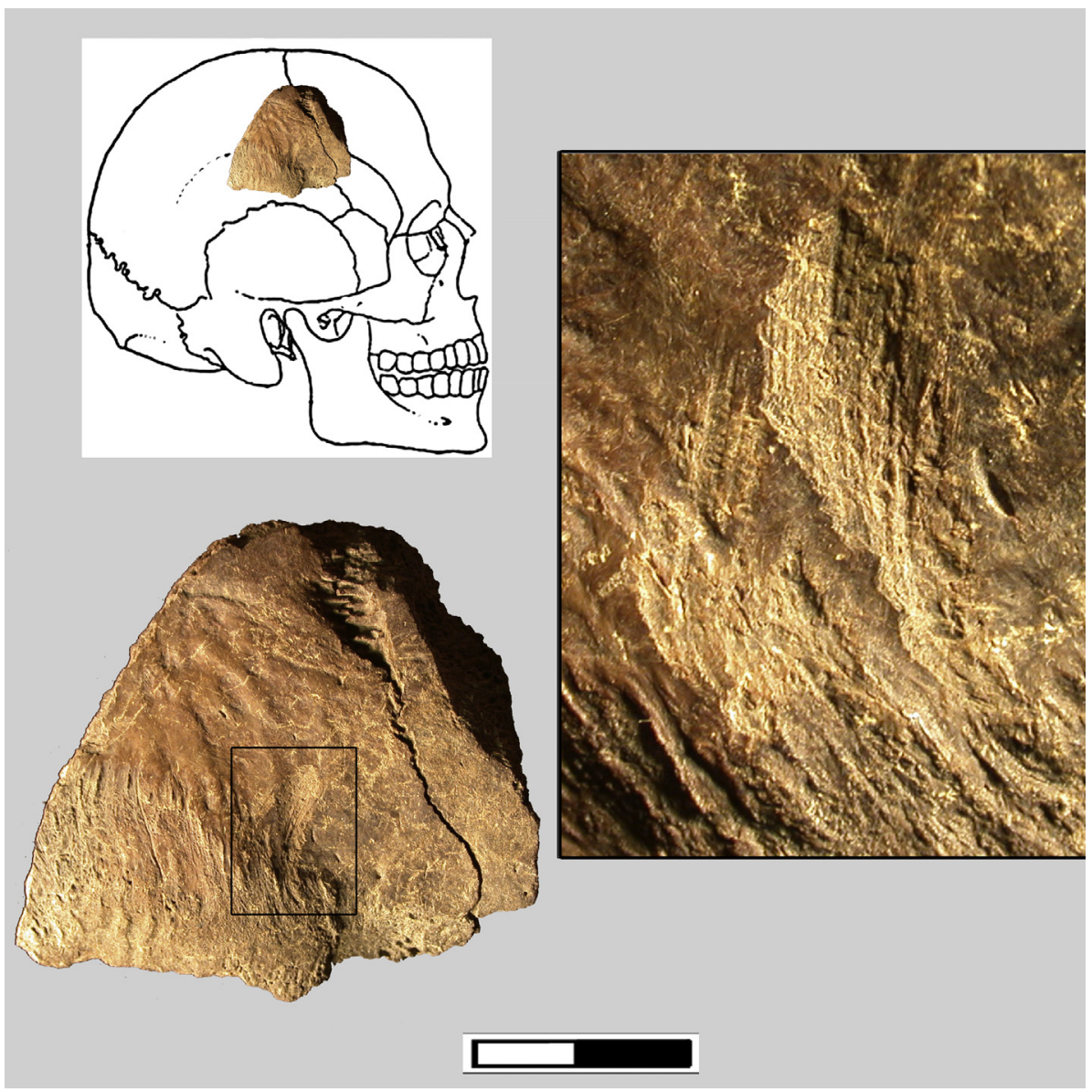

Fig. 11. Frontoparietal fragment of human cranium (SM-W-HS 17) with intense and flat chop marks.

Table 4

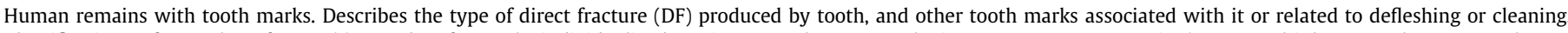

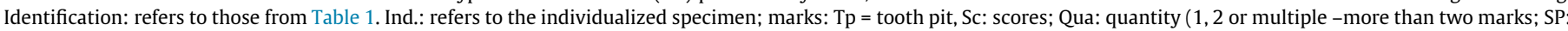

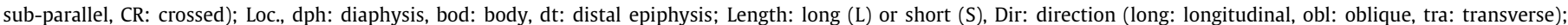
Morph.: morphology; Int.: intensity (Int: intense, Sli: slight); Function: defleshing (DFL) and breakage (BRK).

\begin{tabular}{|c|c|c|c|c|c|c|c|c|c|c|c|}
\hline Identification & Indiv. & DF & Marks & Qua & Loc. & Length & Dir. & Morph. & Int. & Function & Fig. \\
\hline SM-W-HS 18 & $?$ & - & Tp, Sc & 2 & dph & $\mathrm{S}$ & tra & Flat & Sli & DFL & $12-14$ \\
\hline SM-W-HS 5 & $?$ & - & $\mathrm{Tp}, \mathrm{Sc}$ & 1 & dph & $\mathrm{S}$ & tra & Flat & Sli & DFL & 15 \\
\hline SM-W-HS 19 & $\mathrm{R}$ & - & Tp, Sc & 4 & dph & $\mathrm{S}$ & & Flat & Sli & DFL & 7b1-b4 \\
\hline SM-W-HS 29 & $?$ & - & $\mathrm{Tp}, \mathrm{Sc}$ & 1 & dph & $\mathrm{S}$ & tra & Flat & Sli & DFL & 16 \\
\hline SM-W-HS 12 & $?$ & - & $\mathrm{Tp}, \mathrm{Sc}$ & 1 & dph & $S$ & obl & Flat & Sli & DFL & $6 b$ and $c$ \\
\hline SM-W-HS 11 & $\mathrm{R}$ & - & Sc & Mult, SP & Bod & $\mathrm{S}$ & tra & Flat & Int & DFL & 17 \\
\hline SM-W-HS-23 & $?$ & - & Sc & Mult CR & dph & $\mathrm{L}$ & - & Flat & Sli & DFL & 18 \\
\hline SM-W-HS 11 & $\mathrm{R}$ & Notches & Tsc & - & - & - & - & - & - & BRK & 5 \\
\hline SM-W-HS 3 & $?$ & Peeling & $\mathrm{Tp}$ & - & - & - & - & - & - & BRK & 20 \\
\hline
\end{tabular}

(1) Direct proof: the presence of human bones within human coprolites or the identification of human bites on human bones.

(2) Indirect proof: mainly cooking or pot polish marks.

(3) First-order primary criteria: anthropogenic fracture and differential anatomical representation (if this anomalous representation is not related to post-depositional processes but to the functional exploitation of the bones).

(4) Second-order primary criteria: mainly cut marks.

(5) Secondary criteria that are not directly related to functional exploitation: position and preservation of the bones and presence of burned bones.

In the case of our study, the human remains recovered from the archaeological site of Santa Maira are mixed with animal remains.
There are no differences in terms of preservation, macroscopic aspects or taphonomic alterations between the human bones and those from other animal taxa. Furthermore, the different types of anthropic marks that have been identified on human remains are similar to those observed on prey consumed by the Mesolithic hunters of the region: ibex (Capra pyrenaica), red deer (Cervus elaphus), wild boar (Sus scrofa), chamois (Rupicapra rupicapra), fox (Vulpes vulpes) and rabbit (Oryctolagus cuniculus) (Aura Tortosa et al., 2006; Morales Pérez, 2013, 2015).

Caprinae are the main prey of the human groups found in the Mesolithic levels of the site. If we compare the frequency of human and Caprinae remains that present anthropic marks, no statistically significant differences are seen; this is the case of lithic cut and scrape marks (Yates $\chi^{2}=0.62 ; \mathrm{df}=1 ; \mathrm{p}>0.05$ ), fracture impacts (Fisher Exact Test $\mathrm{p}>0.05$ ) and thermo-alterations (Yates 


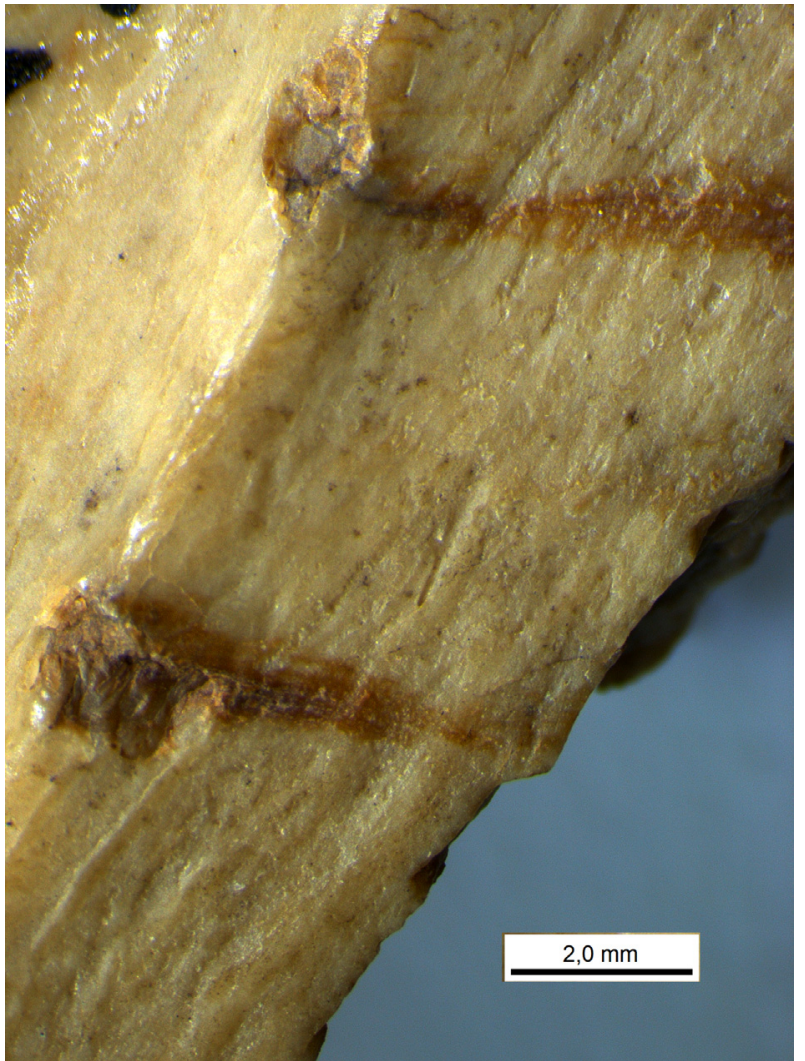

Fig. 12. Femur shaft fragment SM-W-HS 18 with two pits associated with shallow scores.

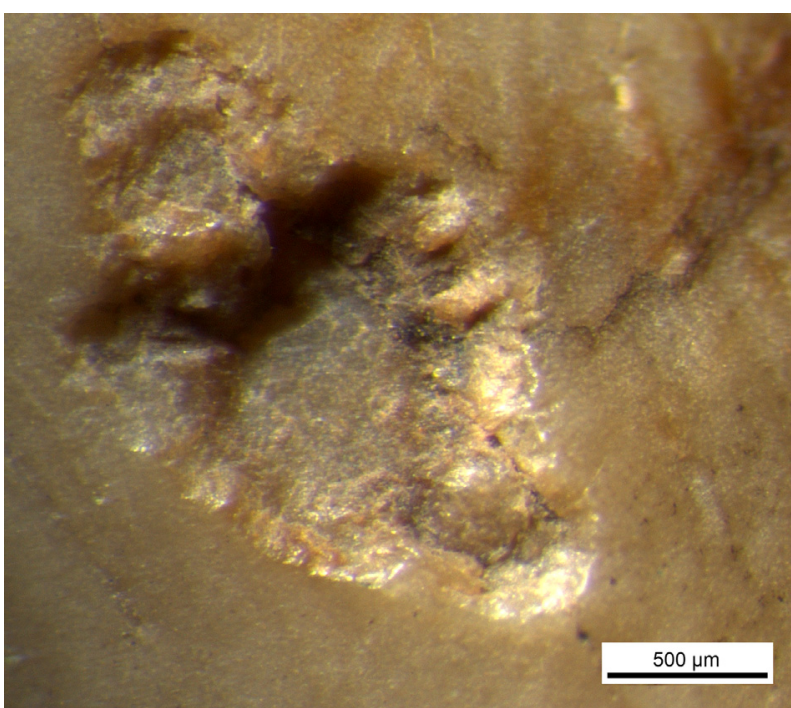

Fig. 13. Detail of a triangular-shaped pit from SM-W-HS 18. $2.24 \times 1.23 \mathrm{~mm}$.

$\left.\chi^{2}=0.39 ; \mathrm{df}=1 ; \mathrm{p}>0.05\right)$. These estimations take into account all the Caprinae remains identified in SM-3. Teeth and horn cores have not been included, since teeth are overrepresented in the sample of Caprinae and horns cannot be compared to human remains (Table 7). Together, these similarities in the statistical values and the marks resulting from dental action strengthen our hypothesis about the anthropic processing and consumption of the human remains described here.

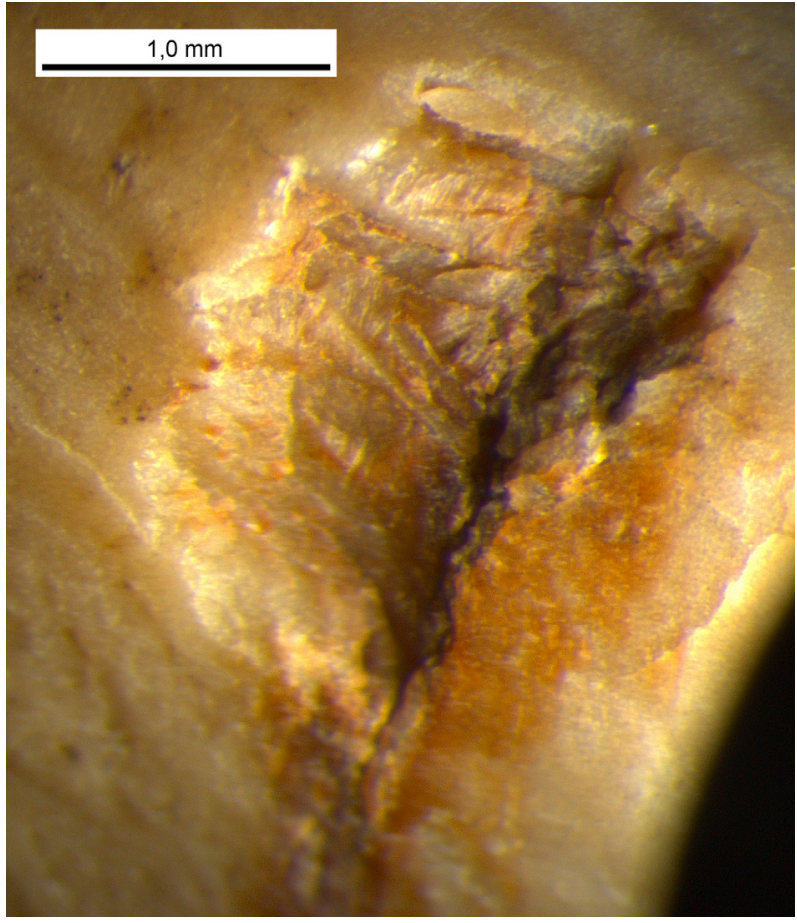

Fig. 14. Detail of a sub-rectangular pit from SM-W-HS $18.1 .35 \times 1.68 \mathrm{~mm}$.

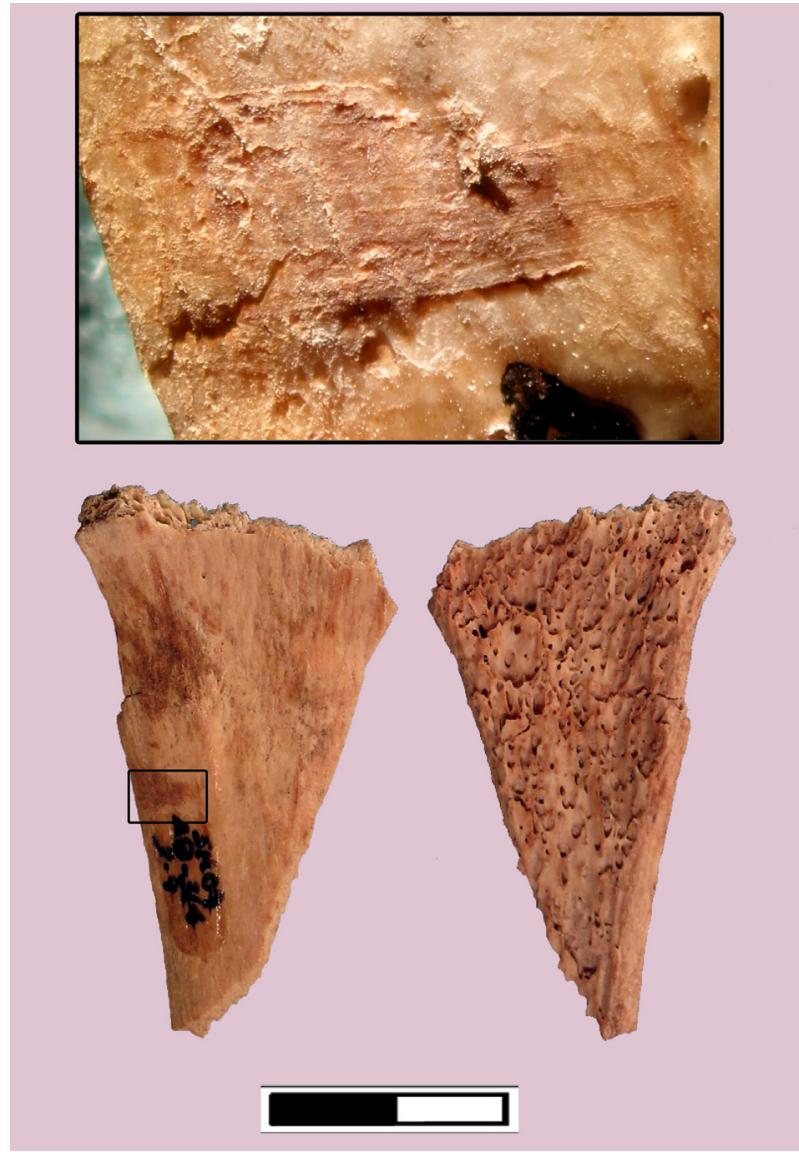

Fig. 15. Tibial shaft fragment SM-W-HS 29. In detail, a crescent pit associated with a shallow and wide scores. 


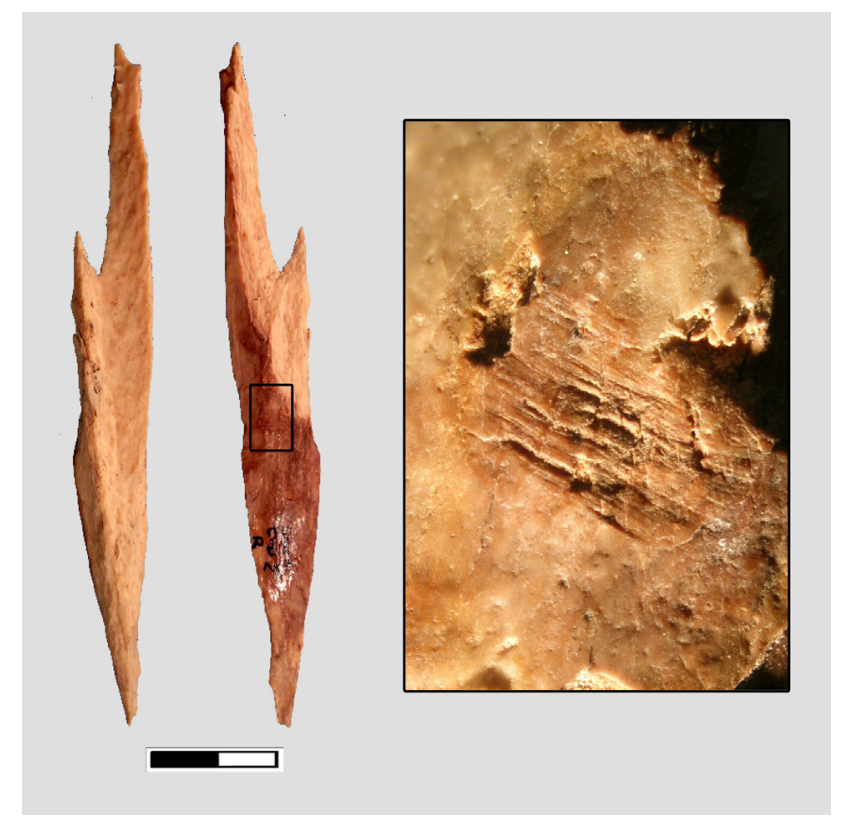

Fig. 16. Femur or tibia shaft fragment SM-W-HS 5. In detail, a sub-rectangular pit associated with shallow and wide scores. Thermo-alteration only affects the external cortex.

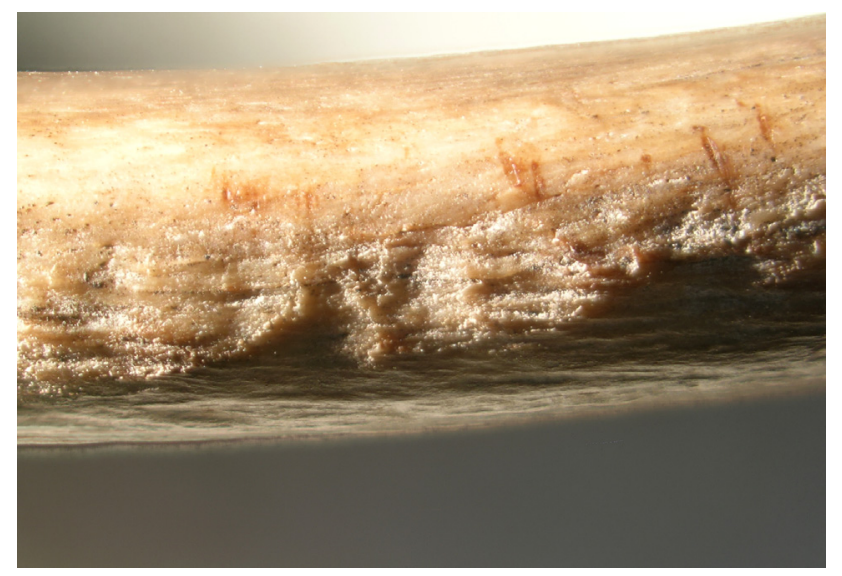

Fig. 17. Rib fragment SM-W-HS 11 with shallow scores or elongated subrectangular pits on the intercostal caudal edge. The mean width of these marks is $2.13 \mathrm{~mm}(\max =3.96 ; \min =1.15 ; \mathrm{STD}=1.08)$. These marks are associated with smaller scores.

As well as their similarity with other animal species in terms of how they have been treated, the human remains found in Santa Maira meet all the criteria proposed by Boulestin (1999) in order to be considered consumed. Thermo-alterations deserve more extensive discussion, since at least five diaphysis fragments only show thermo-alterations on their external surface but not on their internal surface or fracture edges. This implies that they were slightly exposed to fire before they were fractured and supports the burns to be a constituent part of the butchering process. Of these remains, four from the same femur and two from a tibia or femur diaphysis with a similar size and thickness probably belong to the same robust specimen. This individual could have been processed in such a way that it was subjected to thermal treatment before it was fractured, perhaps with the intention of facilitating the extraction of the bone marrow, as suggested in other cases (Botella et al., 2000).

For all of the above-mentioned reasons, we consider that there are clear marks of anthropic origin on the human remains found at
Santa Maira. Moving on, the cause and meaning of anthropogenic practices at the site in question should also be discussed. There are diverse chronological and cultural contexts that document this phenomenon, making it difficult to find a common reason for its existence. Once again, Boulestin (1999) proposes a systematic approach by dividing these practices into two types: (a) the exceptional, where anthropophagy might be motivated by a specific need, and (b) the socially instituted, both endocannibalism and exocannibalism, which may result from violence, war, funeral rituals or supernatural beliefs. This variety in the types of anthropophagy suggests that its correct identification and analysis should always refer to the cultural and archaeological contexts in which it is framed as a social practice, ruling out simple causalities.

The association of the human remains found at Santa Maira (mainly appendicular, small and highly fragmented) with different species of mountain and forest mammals indicates that the huntergatherers exploited at least these types of environments. Furthermore, the presence of molluscs and fish bones (e.g. Mytilus edulis, Cardium edulis, Mugilidae sp., Sparidae sp.) suggests that the coastal areas were also exploited (Aura Tortosa et al., 2015). We are therefore dealing with groups that combine the exploitation of different resources and ecosystems: they used the inland mountain areas for hunting ibex, the forest for hunting red deer and the coastal plain to procure fish and seafood (Salazar-García et al., 2014; Morales Pérez, 2013). Furthermore, stable carbon and nitrogen isotope analysis carried out on Mesolithic human and faunal remains from sites in the region, like El Collado (García-Guixé et al., 2006), Penya del Comptador and Santa Maira itself (Salazar-García et al., 2014), support the subsistence pattern described here. The Mesolithic populations from the region were clearly capable of exploiting both terrestrial and marine resources, making it unlikely that anthropophagic practices were due entirely to nutritional needs. In any case, we should not completely ignore another possibility suggested by some authors (Villa et al., 1988): that "microhistoric" anthropophagic events in areas or ecosystems with a mild climate and plenty of available resources might be the result of periodic food stress or an exceptional dietary imbalance (Schulting et al., 2015). Taking this last possibility into account, the scarcity of human remains, and the fact that their peri-depositional features are similar to those presented by the butchered and consumed remains of other species, could suggest a kind of occasional anthropophagy. If this is the case, it would be yet another element of the diversification seen at these levels.

Another possibility that would explain the presence of anthropophagy at Santa Maira is that of institutionalized cannibalism. However, this type of anthropophagic practice - regardless of whether it is endocannibalism or exocannibalism-has not been yet clearly identified during the Upper Palaeolithic and the Mesolithic in the Mediterranean region.

In North African sites of Iberomaurusian and Capsian contexts there are dismembered human remains with cut marks associated with secondary burials (Belcastro et al., 2010; Haverkort and Lubell, 1999; Mariotti et al., 2009). In the Mediterranean Iberian Upper Palaeolithic, human remains with anthropic marks are scant and are limited to the site of Cova Beneito. These are mainly isolated cranial remains and they have been interpreted as resulting from secondary burials (Iturbe et al., 1993).

Furthermore, in southern European Neolithic sites, the classical interpretation of cannibalism resulting from nutritional needs has recently been challenged. A reinterpretation of the material from Fontbrégoua (Le Bras-Goude et al., 2010) and Scaloria (Robb et al., 2015) suggests that disarticulation and anthropic marks on human remains could possibly be the result of funerary practices rather than cannibalism. However, it seems that this is the point when social conflicts deriving from new socio-economic structures 


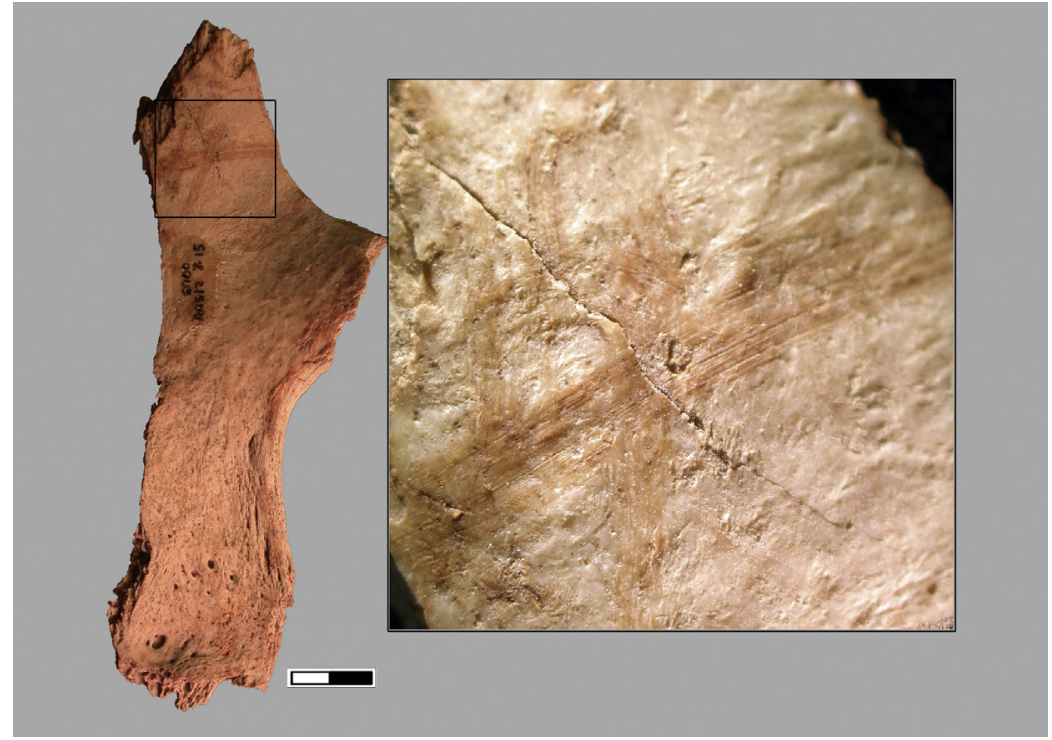

Fig. 18. Iliac fragment SM-W-HS 23 with wide flat and slight scores (width $\max =1.37 \mathrm{~mm} ; \mathrm{min}=0.85 \mathrm{~mm}$ ).

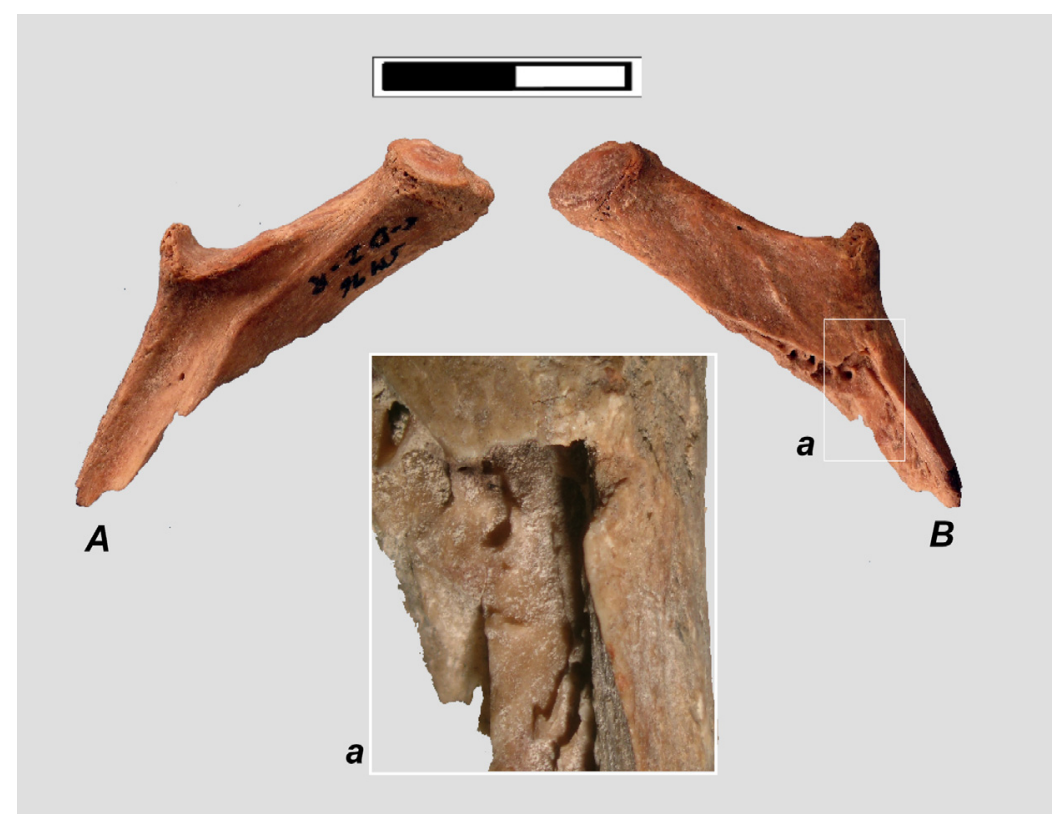

Fig. 19. Vertebral end of a Capra pyrenaica rib with two notches caused by human tooth.

appear to lead to the recognition of this type of institutionalized cannibalism in other regions of Europe (Boulestin et al., 2009).

With regard to the Mesolithic, there is currently no other evidence of anthropic marks on human remains in the western Mediterranean. However, there is a clear increase in human remains compared to previous times (Aura Tortosa, 2010). This, together with an increase in the number of isolated disarticulated human remains from multiple burials in rock shelters and from open-air cemeteries (Gibaja et al., 2015; Meiklejohn et al., 2009), shows how ritual complexity was clearly increasing with respect to previous ages at the time when the human remains with anthropic marks appear at Santa Maira. These new mortuary practices have been related to a higher stability of camps dedicated to diversified economies, as a result of competitiveness and confrontation between local groups (Rowley-Conwy, 2001), and linked to a critical period (the regional Epipalaeolithic-Mesolithic transition) in which cannibalism and socio-cultural transformation phases are associated with each other (Boulestin, 2014). However, it must be noted that there is no archaeological evidence to support an association between the human remains from Santa Maira and an episode of violence resulting from this context of tension, either at an individual level or at group level.

It is therefore difficult to establish the type of cannibalism that has been found at Santa Maira with any certainty. However, certain aspects are clear: (1) the data available at present show anthropophagic practice with few - isolated - human remains, and they have been deposited in a similar manner to other butchered remains; (2) direct radiocarbon dating of two different individuals suggests that the human remains come from at least two different moments; (3) these practices coincide with times of rapid change 


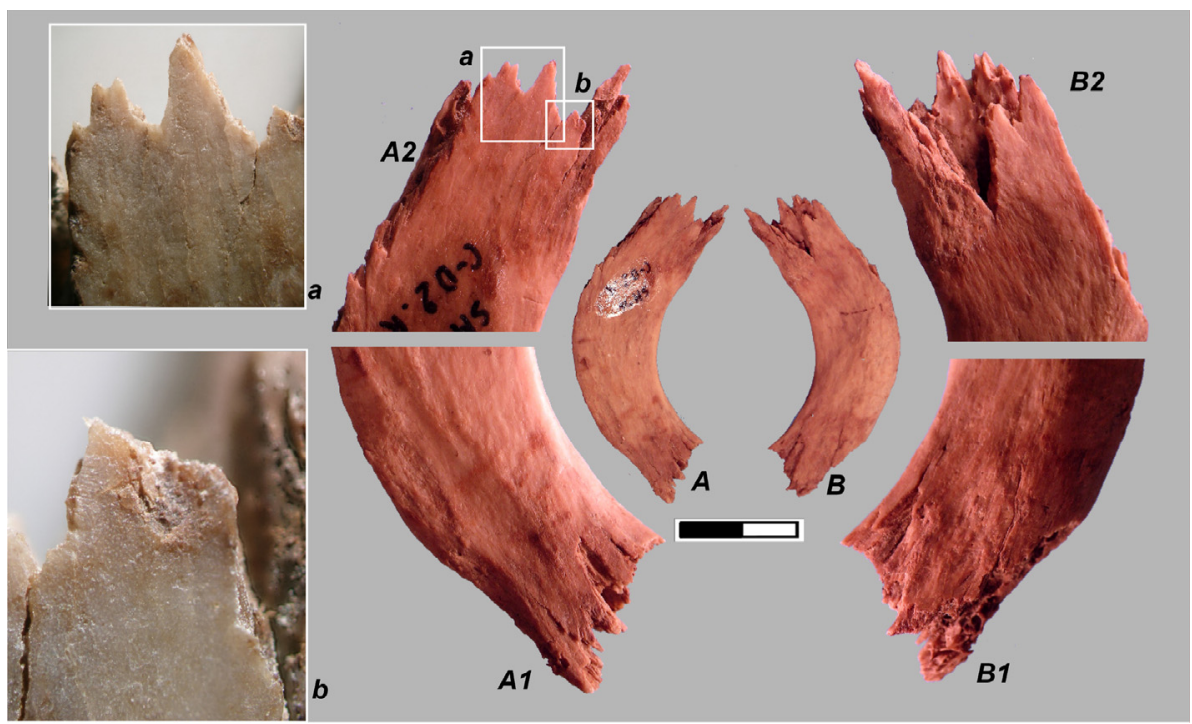

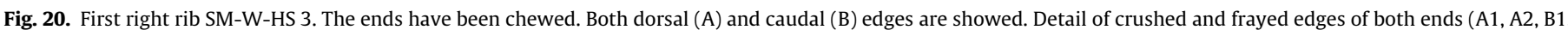
B2). Detail of small notch (a) and puncture (b). Crenulation width: $\max =1.58, \min =0.36$; puncture/pit width $\max =0.42, \min =0.1$.

Table 5

Fractured human bones with impact marks. Identification: refers to those from Table 1. Ind.: refers to the individualized specimen. Impacts: quantity of impact marks detected.

\begin{tabular}{llll}
\hline Identification & Ind. & Impacts & Fig \\
\hline SM-W-HS 13 & $?$ & 3 & 21 \\
SM-W-HS 24 & R & 1 & 8 \\
SM-W-HS 26 & R & 2 & $9 \mathrm{~b}$ and c \\
SM-W-HS 34 & S & 1 & $10 \mathrm{~b}$ \\
\hline
\end{tabular}

in terms of exploitation of the land and technology. For the moment, it is not possible to say whether these matters are independent or associated to each other.

\section{Conclusions}

A generally accepted criterion for the identification of anthropophagic behaviours is that human remains that have supposedly been subjected to cannibalism have previously been treated and discarded in the same way as those of common animal prey. The taphonomic study and manipulation marks (lithic, tooth, percussion and fire marks) from level 3 of Santa Maira are compatible with the accepted criteria for defining anthropophagic practices. These anthropic marks on human remains have made it possible to identify all the butchering process: from body disarticulation to others more directly related to consumption, such as thermoalterations, tooth marks or bone fractures. Furthermore, the presence of human remains together with other animal remains has made it possible to compare human marks with ibex and red deer marks from the same archaeological level, and show that overall they were processed in a similar way.

Results from level 3 of Santa Maira have also led to the discussion of two main hypotheses about the kind of anthropophagic behaviour: occasional or institutional cannibalism. Human consumption as a result of nutritional stress requirements seems unlikely due to the broad spectrum of resources consumed by Mesolithic populations in the region. However, the small quantity of human bones, their radiocarbon results and taphonomic history seem to suggest that anthropophagy in Santa Maira was an exceptional fact. On the other hand, the archaeological context during the Epipalaeolithic-Mesolithic transition in the region, with an

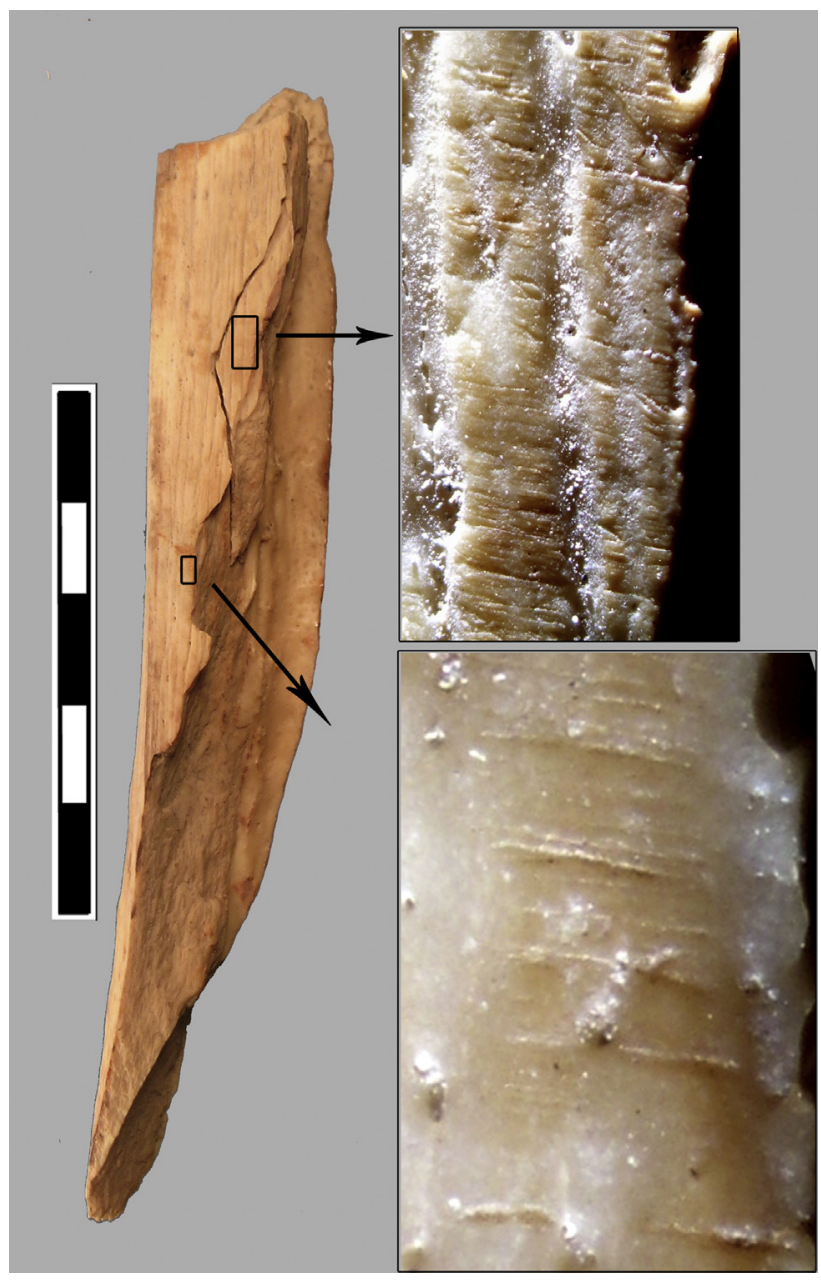

Fig. 21. Tibial shaft fragment SM-W-HS 13 with three direct impacts. In detail, two impacts with light and wide scores associated.

increase in social complexity and burial rituals, could mean that the human remains from Santa Maira result from institutionalized behaviour, or at least that their appearance within this context 
Table 6

Bones with fire marks. Identification numbers refer to those from Table 1. Ind. refers to the two (individualized) specimen: the gracile $(G)$ and the more robust (R) ones: Colour: Brown $(\mathrm{Br})$ or Brown and Black $(\mathrm{Br}-\mathrm{Bl})$; Loc: shows the affected area of the bone (I-E: internal and external surfaces affected, E: external surface affected), Extent: shows the extent of the fire marks (T: total, P: partial).

\begin{tabular}{lllll}
\hline Identification & Ind. & Colour & Loc. & Extent \\
\hline SM-W-HS 1 & $?$ & $\mathrm{Br}-\mathrm{Bl}$ & $\mathrm{I}-\mathrm{E}$ & $\mathrm{T}$ \\
SM-W-HS 3 & $?$ & $\mathrm{Br}$ & $\mathrm{I}-\mathrm{E}$ & $\mathrm{P}$ \\
SM-W-HS 4 & $?$ & $\mathrm{Br}-\mathrm{Bl}$ & $\mathrm{I}-\mathrm{E}$ & $\mathrm{P}$ \\
SM-W-HS 5 & $\mathrm{R}$ & $\mathrm{Br}$ & $\mathrm{E}$ & $\mathrm{P}$ \\
SM-W-HS 12 & $?$ & $\mathrm{Br}$ & $\mathrm{E}$ & $\mathrm{P}$ \\
SM-W-HS 17 & $?$ & $\mathrm{Br}-\mathrm{Bl}$ & $\mathrm{I}-\mathrm{E}$ & $\mathrm{T}$ \\
SM-W-HS 19 & $\mathrm{R}$ & $\mathrm{Br}$ & $\mathrm{I}-\mathrm{E}$ & $\mathrm{P}$ \\
SM-W-HS 20 & $\mathrm{S}$ & $\mathrm{Br}-\mathrm{Bl}$ & $\mathrm{I}-\mathrm{E}$ & $\mathrm{T}$ \\
SM-W-HS 21 & $?$ & $\mathrm{Br}$ & $\mathrm{I}-\mathrm{E}$ & $\mathrm{P}$ \\
SM-W-HS 24 & $\mathrm{R}$ & $\mathrm{Br}$ & $\mathrm{E}$ & $\mathrm{P}$ \\
SM-W-HS 25 & $?$ & $\mathrm{Br}$ & $\mathrm{E}$ & $\mathrm{P}$ \\
SM-W-HS 26 & $\mathrm{R}$ & $\mathrm{Br}$ & $\mathrm{E}$ & $\mathrm{P}$ \\
SM-W-HS 27 & $\mathrm{R}$ & $\mathrm{Br}$ & $\mathrm{E}$ & $\mathrm{P}$ \\
SM-W-HS 30 & $?$ & $\mathrm{Br}$ & $\mathrm{I}-\mathrm{E}$ & $\mathrm{P}$ \\
SM-W-HS 31 & $?$ & $\mathrm{Br}$ & $\mathrm{E}$ & $\mathrm{P}$ \\
SM-W-HS 34 & $\mathrm{S}$ & $\mathrm{Br}$ & $\mathrm{I}-\mathrm{E}$ & $\mathrm{P}$ \\
SM-W-HS 35 & $?$ & $\mathrm{Br}$ & $\mathrm{I}-\mathrm{E}$ & $\mathrm{P}$ \\
SM-W-HS 36 & $?$ & $\mathrm{Br}$ & $\mathrm{I}-\mathrm{E}$ & $\mathrm{P}$ \\
SM-W-HS 37 & $?$ & $\mathrm{Br}$ & $\mathrm{I}-\mathrm{E}$ & $\mathrm{T}$ \\
\hline
\end{tabular}

\section{Table 7}

Presence or absence of the three types of anthropogenic marks in the two different groups, human and Caprinae remains from SM-3. Antlers and teeth have been excluded.

\begin{tabular}{|c|c|c|c|c|c|c|c|}
\hline & \multirow[t]{2}{*}{ Total } & \multicolumn{2}{|c|}{ Lithic marks } & \multicolumn{2}{|c|}{ Impact point } & \multicolumn{2}{|c|}{ Fire marks } \\
\hline & & With & Without & With & Without & With & Without \\
\hline Human & 27 & 9 & 18 & 4 & 23 & 19 & 8 \\
\hline Caprinae & 383 & 94 & 289 & 55 & 327 & 239 & 144 \\
\hline
\end{tabular}

could be related to general changes in cultural and economic traditions as well as the increase in territorial behaviour of human groups.

\section{Acknowledgments}

The fieldwork in Coves de Santa Maira was authorized and funded by the Generalitat Valenciana. The analysis of human remains and palaeoconomic studies are part of the project LongTransMed (Project: HAR2013-46861-R), which is funded by the Spanish Ministry of Economy and Competitiveness. DCSG acknowledges funding from the Generalitat Valenciana (VALi+d APOSTD/2014/123), the BBVA Foundation (I Ayudas a investigadores, innovadores y creadores culturales) and the European Union (FP7/2007-2013 - MSCA-COFUND, n²45743 via a BraudelIFER-FMSH). The collection is deposited in the Museu Arqueològic Municipal d'Alcoi (Alicante, Spain). The authors would also like to thank the anonymous reviewers for their comments and explanations, which have helped to improve and clarify this paper.

\section{References}

Arens, W., 1979. The Man-Eating Myth. Oxford Univ. Press, New York. Aura Tortosa, JE Jordá, JF Montes, L Utrilla, P. 2011. Human responses to Younger Dryas in the Ebro valley and Mediterranean watershed (Eastern Spain). Quatern. Int. 242 (2), 348-359.

Aura Tortosa, JE 2010. Uno de los nuestros. Notas para una arqueología de las prácticas funerarias de los cazadores prehistóricos de la península ibérica. In: Pérez Fernández, A., Soler Mayor, B. (Eds.), Restos de vida, restos de muerte. Diputació de Valencia, Museu de Prehistoria, CAM, Valencia, pp. 31-44.

Aura Tortosa, J.E. Marlasca Martín, R, Rodrigo García, M.J. Jordá, J.F., Salazar-García, D.C., Morales Pérez, J.V., Pérez Ripoll, M., 2015. Llisses, orades i alguna anguila. L'ictiofauna mesolítica de les coves de Santa Maira (Castell de Castells, la Marina
Alta, Alacant. In: Sanchis Serra, A., Pascual Benito, J.L. (Eds.), Petites preses i grups humans en el passat. II Jornades d'Arqueozoologia. Museu de Prehistòria de València, València, pp. 121-138.

Aura Tortosa, J.E., Carrión Marco, Y., García Puchol, O., Jardón Giner, P., Jordá Pardo, J. F., Molina Balaguer, L., Morales Pérez, J.V., Pascual Benito, J.L., Pérez Jordà, G., Pérez Ripoll, M., Rodrígo García, M.J., Verdasco Cebrián, C.C., 2006. Epipaleolítico-Mesolítico en las comarcas centrales valencianas. In: Alday, A. (Ed.), El mesolítico de muescas y denticulados en la cuenca del Ebro y el litoral mediterráneo peninsular, Arbak Foru Aldundia, Vitoria-Gasteiz, pp. 65-118.

Belcastro, M.G., Condemi, S., Mariotti, V., 2010. Funerary practices of the Iberomaurusian population of Taforalt (Tafoughalt, Morocco, 11-12,000 BP): the case of Grave XII. J. Hum. Evol. 58, 522-532.

Bello, S.M., Saladié, P., Cáceres, I., Rodríguez-Hidalgo, A., Parfitt, S.A., 2015. Upper Palaeolithic ritualistic cannibalism at Gough's Cave (Somerset, UK): the human remains from head to toe. J. Hum. Evol. 82, 170-189.

Binford, L.R., 1981. Bones. Ancient Men and Modern Myths. Academic Press, Orlando.

Blasco, R., Rosell, J., 2009. Who was the first? An experimental application of carnivore and hominid overlapping marks at the Pleistocene archaeological sites. C.R. Palevol 8, 579-592.

Botella, M.C., 2005. Diagnóstico diferencial de las marcas de corte sobre los huesos humanos. In: Cañellas Trobat, A. (Ed.), Nuevas perspectivas del diagnóstico diferencial en paleopatología. Actas del VII Congreso Nacional de Paleopatología (Mahón-Menorca, 02 al 05 de octubre de 2003). Universitat de les Illes Balears, Mahon, pp. 87-100.

Botella, M.C., Alemán, I., García, C.J., 2001. Marcas en los huesos humanos. In: Campillo, D. (Ed.), Introducción a la paleopatología, Bellaterra, Barcelona, pp. 408-420.

Botella, M.C., Alemán, I., Jiménez, S.A., 2000. Los huesos humanos. Manipulación y alteraciones, Bellaterra, Barcelona.

Boulestin, B., 1999. Approche taphonomique des restes humains. Le cas des Mésolithiques de la grotte des Perrats et le problème du cannibalisme en préhistoire récente européenne, Oxford.

Boulestin, B., Zeeb-Lanz, A., Jeunesse, C., Haack, F., Arbogast, R.M., Denaire, A., 2009. Mass cannibalism in the Linear Poterry Culture at Herxheim (Palatinate, Germany). Antiquity 83, 962-982.

Boulestin, B., 2014. Manger son ennemi: le cannibalisme préhistorique et la "guerre". In: Buchsenschutz, O., Dutour, O., Mordant, C. (Eds.), Archéologie de la violence et de la guerre dans les sociétés pré et protohistoriques. CTHS, Paris, pp. 37-52.

Brain, C.K., 1981. The Hunters or the Hunted? An Introduction to African Cave Taphonomy. University of Chicago Press, Chicago.

Buikstra, J.E., Ubelaker, D.H., 1994. Standards for data collection from Human Skeletal Remains. Arkansas Archeological Survey.

Cáceres, I., Lozano, M., Saladié, P., 2007. Evidence for bronze age cannibalism in El Mirador Cave (Sierra de Atapuerca, Burgos, Spain). Am. J. Phys. Anthropol. 133, 899-917.

Campmas, É., Beauval, C., 2008. Consommation osseuse des carnivores: résultats de l'étude de l'exploitation de carcasses de boeufs (Bos taurus) par des loups captifs. Ann. Paléontol. 94, 167-186.

Capasso, L., Kennedy, K.A.R., Wilczak, C.A., 1998. Atlas of Occupational Markers on Human Remains. Edigrafital S.P.A., Teramo.

Carbonell, E., Cáceres, I., Lozano, M., Saladié, P., Rosell, J., Lorenzo, C., Vallverdú, J., Huguet, R., Canals, A. Bermúdez de Castro, J.M., 2010. Cultural cannibalism as a Paleoeconomic system in the European Lower Pleistocene. Curr. Anthropol. 51, 539-549.

Cochard, D., 2004. Etude taphonomique des léporidés d'une tanière de renard actuelle: apport d'un référentiel à la reconnaissance des accumulations anthropiques. Rev. Paléobiol. 23 (2), 659-673.

Defleur, A., Dutour, O., Valladas, H., Vandermeersch, B., 1993. Cannibals among the neanderthals? Nature 362, 214.

Delaney-Rivera, C., Plummer, T.W., Hodgson, J.A., Forrest, F., Hertel, F., Oliver, J.S., 2009. Pits and pitfalls: taxonomic variability and patterning in tooth mark dimensions. J. Archaeol. Sci. 36, 2597-2608.

Diamond, J.M., 2000. Talk of cannibalism. Nature 407, 25-26.

Domínguez-Rodrigo, M., Piqueras, A., 2003. The use of tooth pits to identify carnivore taxa in tooth-marked archaeofaunas and their relevance to reconstruct hominid carcass processing behaviours. J. Archaeol. Sci. 30, 13851391.

Fernández-Jalvo, Y., Andrews, P., 2011. When humans chew bones. J. Hum. Evol. 60, 117-123.

Fernández-Jalvo, Y., Carlos Díez, J., Cáceres, I., Rosell, J., 1999. Human cannibalism in the Early Pleistocene of Europe (Gran Dolina, Sierra de Atapuerca, Burgos, Spain). J. Hum. Evol. 37, 591-622.

Galán, A.B., Rodríguez, M., de Juana, S., Domínguez-Rodrigo, M., 2009. A new experimental study on percussion marks and notches and their bearing on the interpretation of hammerstone-broken faunal assemblages. J. Archaeol. Sci. 36, 776-784.

García Guixé, E, Richards, M. Subirà, M.E, 2006. Palaeodiets of humans and fauna at the Spanish Mesolithic site of El Collado. Curr. Anthropol. 47, 549556.

Garralda, M.D., Giacobini, G., Vandermeersch, B., 2003. Huellas de manipulación intencional en dos neandertales de Combe-Grenal (Domme, Francia). In: Campo Martín, M., Robles Rodríguez, F. (Eds.), ¿Dónde estamos? Pasado, presente y futuro de la Paleopatología. VI Congreso Nacional de Paleopatología, Madrid, 13 a 16 de septiembre 2001, Madrid, pp. 139-147. 
Garrigou, M.F., 1870. Traces de l'anthropophagie dans les temps antéhistoriques, découvertes dans la grotte de Montesquieu - Avantes (Ariége). C. R. Séances l'Académie Sci. 70, 167-169.

Gibaja, J.F., Subirà, M.E., Terradas, X., Santos, F.J., Agulló, L., Gómez-Martínez, I., Allièse, F., Fernández-López de Pablo, J., 2015. The emergence of Mesolithic cemeteries in SW Europe: insights from the El Collado (Oliva, Valencia, Spain) radiocarbon record. PLOS ONE 10 (1).

Gifford-Gonzalez, D., 1989. Ethnographic analogues for interpreting modified bones: some cases form East Africa. In: Bonnichsen, R., Sorg, M.H. (Eds.), Bone Modification. Center for the Study of the First Americans, Orono, pp. 179-246.

Gray Jones, A., 2011. Dealing with the dead: manipulation of the body in the mortuary practices of Mesolithic north-west Europe Ph. D. Thesis. University of Manchester.

Haverkort, C.M., Lubell, D., 1999. Cutmarks on capsian human remains: implications for Maghreb holocene social organization and palaeoeconomy. Int. J. Osteoarchaeol. 9, 147-169.

Haynes, G., 1980. Evidence of carnivore gnawing on Pleistocene and recent mammalian bones. Paleobiology 6 (3), 341-351.

Iturbe, G., Fumanal García, M.P., Carrión, J.S., Cortell, E., Martínez, R., Guillem, P.M., Garralda, M.D., Vandermeersch, B., 1993. Cova Beneito (Muro, Alicante). Una perspectiva interdisciplinar. Recerques del Museu d'Alcoi 2, 23-88.

Kolata, G., 1986. Anthropologists suggest cannibalism is a myth. Science 232, 1497 1500.

Krajcarz, M., Krajcarz, M.T., 2014. The red fox (Vulpes vulpes) as an accumulator of bones in cave-like environments. Int. J. Osteoarchaeol. 24, 459-475.

Landt, M.J., 2004. Investigations on human gnawing on small mammal bones among contemporary Bofi foragers of the Central African Republic Unpublished MA dissertation. Washington State University.

Le Bras-Goude, G., Binder, D., Zemour, A., Richards, M.P., 2010. New radiocarbon dates and isotope analysis of Neolithic human and animal bone from the Fontbrégoua Cave (Salernes, Var, France). J. Antropol. Sci. 88, 167-178.

Lloveras, L., Moreno-García, M., Nadal, J., 2012. Feeding the foxes: an experimental study to assess their taphonomic signature on leporid remains. Int. J. Osteoarchaeol. 22, 577-590.

Lyman, R.L., 1994. Vertebrate Taphonomy. Cambridge University Press, Cambridge.

Mariotti, V., Bonfiglioli, B., Facchini, F., Condemi, S., Belcastro, M.G., 2009. Funerary practices of the Iberomaurusian population of Taforalt (Tafoughalt; Morocco, $11-12,000 \mathrm{BP}$ ): new hypotheses based on a grave by grave skeletal inventory and evidence of deliberate human modification of the remains. J. Hum. Evol. 56, 340-354.

Marlar, R.A., Leonard, B.L., Billman, B.R., Lambert, P.M., Marlar, J.E., 2000. Biochemical evidence of cannibalism at a prehistoric Puebloan site in southwestern Colorado. Nature 407, 74-78.

Meiklejohn, C., Brinch Petersen, E., Babb J., 2009. From single graves to cemeteries: An initial look at chronology in Mesolithic burial practice, In: McCartan, S.B., Schulting, R. Warren, R., Woodman, P., (Eds.), Mesolithic horizons. Papers presented at the seventh international conference on the Mesolithic in Europe, Belfast 2005, Oxbow books; Oxford, pp. 639-649.

Morales Pérez, J.V., 2013. La transició del Paleolític Superior Final/Epipaleolític al Mesolític en el territori valencià. Aportacions de l'estudi zooarqueològic del jaciment de Santa Maira (Castell de Castells, Alacant). In: Sanchis Serra, A. Pascual Benito, J.L. (Eds.), Animals i Arqueologia hui. I jornades d'Arqueozoologia del Museu de Prehistòria de València. Museu de Prehistòria de Valencia, València, pp. 181-202.

Morales Pérez, J.V., 2015. Explotació dels mamífers i economia de les darreres comunitats caçadores-recol-lectores del vessant mediterrani ibèric durant la transició Tardiglacial-Holocé Ph.D. Thesis. Universitat de València.

Neufeldt, R., 2012. Biasing cannibalism in anthropology. J. Manitoba Anthropol. Student's Assoc. 30

Oliver, J.S., 1993. Carcass processing by the Hadza: bone breakage from butchery to consumption. In: Hudson, J. (Ed.), From Bones to Behavior: Ethnoarchaeological and Experimental Contributions to the Interpretation of Faunal Remains. Southern Illinois University, Carbondale, pp. 200-227.

Outram, A.K., Knüsel, C.J., Knight, S., Harding, A.F., 2005. Understanding complex fragmented assemblages of human and animal remains: a fully integrated approach. J. Archaeol. Sci. 32, 1699-1710.
Pérez Ripoll, M., 1992. Marcas de carnicería, fracturas intencionadas y mordeduras de carnívoros en huesos prehistóricos del Mediterráneo español. Instituto de Cultura Juan Gil-Albert, Alicante.

Pickering, T.R., Wallis, J., 1997. Bone modifications resulting from captive chimpanzee mastication: implications for the interpretation of pliocene archaeological faunas. J. Archaeol. Sci. 24, 1115-1127.

Pobiner, B.L., DeSilva, J., Sanders, W.J., Mitani, J.C., 2007. Taphonomic analysis of skeletal remains from chimpanzee hunts at Ngogo, Kibale National Park, Uganda. J. Hum. Evol. 52, 614-636.

Regnault, M., 1869. L'anthropologie des peuples primitifs. Fouilles dans la grotte de Montesquieu (Ariége). Bull. Mémoires Soc. d’Anthropol. Paris 4, 476-486.

Robb, J., Elster, E.S., Isetti, E., Knüsel, C.J., Tafuri, M.A., Traverso, A., 2015. Cleaning the dead: neolithic ritual processing of human bone at Scaloria Cave, Italy. Antiquity 89, 39-54.

Rodríguez-Hidalgo, A., Lloveras, Ll., Moreno-García, M., Saladié, P., Canals, A., Nadal, J., 2013. Feeding behaviour and taphonomic characterization of non-ingested rabbit remains produced by the Iberian Lynx (Lynx pardinus). J. Archaeol. Sci. 40, 3031-3045.

Rosas, A., Martínez-Maza, C., Bastir, M., García-Tabernero, A., Lalueza-Fox, C., Huguet, R., Ortiz, J.E., Torres, T.d., Martinez, E., Cañaveras, J.C., Sánchez-Moral, S. Cuezva, S., Lario, J., Santamaria, D., Rasilla, M.d.l., Fortea, J., 2006. Paleobiology and comparative morpholgy of a late Neandertal sample from El Sidrón (Asturias, Spain). Proc. Natl. Acad. Sci. 103, 19266-19271.

Rowley-Conwy, P., 2001. Time, change and the archaeology of hunter-gatherers: how original is the 'Original affluent society'? In: Hunther-Gatherers: An Interdisciplinary Perspective. Cambridge University Press, Cambridge, pp. 3972.

Saladié, P., Rodríguez-Hidalgo, A., Díez, C., Martín-Rodríguez, P., Carbonell, E., 2013. Range of bone modifications by human chewing. J. Archaeol. Sci. 40, 380-397.

Salazar-García, D.C., Aura, J.E., Olària, C.R., Talamo, S., Morales, J.V., Richards, M.P. 2014. Isotope evidence for the use of marine resources in the Eastern Iberian Mesolithic. J. Archaeol. Sci. 42, 231-240.

Sanchis, A., Morales Pérez, J.V., Pérez Ripoll, M., 2011. Creación de un referente experimental para el estudio de las alteraciones causadas por dientes humanos sobre huesos de conejo. In: Morgado, A., Baena, J., García, D. (Eds.), Actas del Segundo Congreso Internacional de Arqueología experimental. Ronda, Málaga. Noviembre 2008. Universidad de Granada, Granada, pp. 343-349.

Sanchis, A., Pascual, J.Ll., 2011. Análisis de las acumulaciones óseas de una guarida de pequeños mamíferos carnívoros (Sitjar Baix, Onda, Castellón): implicaciones arqueológicas. Archaeofauna 20,47-71.

Sauqué, V., Rabal-Garcés, R., Sola-Almagro, C., Cuenca-Bescós, G., 2014. Bone accumulation by leopards in the Late Pleistocene in the Moncayo Massif (Zaragoza, NE Spain). PLoS ONE 9 (3), e92144.

Scheuer, L., Black, S., 2000. Developmental juvenile osteology. Elsevier Academic Press.

Schulting, R.J., Bello, S.M., Chandler, B., Higham, T.F.G., 2015. A cut-marked and fractured mesolithic human bone from Kent's Cavern, Devon, UK. Int. J. Osteoarchaeol. 25, 31-44.

Sharon, A.H., 2000. The taphonomy of cannibalism: a review of anthropogenic bone modification in the American Southwest. Int. J. Osteoarchaeol. 10, 4-26.

Shipman, P. 1981. Applications of scanning electron microscopy to taphonomic problems. In: Cantwell, A.M., Griffin, J.B., Rothschild, N.A. (Eds.), The Research Potential of Anthropological Museum Collections. New York Academy of Science, New York, pp. 357-385.

Ubelaker, D.H., 1994. Human Skeletal Remains. Excavation, Analysis, Interpretation. Taraxakum, Washington.

Villa, P., 1992. Cannibalism in Prehistoric Europe. Evol. Anthropol. 1, 93-104.

Villa, P., Courtin, J., Helmer, D., 1988. Cannibalism in old world prehistory. Riv. Antropol. (Suppl LXVI), 47-64.

Villa, P., Mahieu, E., 1991. Breakage patterns of human long bones. J. Hum. Evol. 21, $27-48$

White, T.D., 1992. Prehistoric Cannibalism at Mancos 5MTUMR-2346. Princeton University Press, Princeton.

Young, A., Stillman, R., Smith, M.J., Korstjens, A.H., 2015. Scavenger species-typical alteration to bone: using bite mark dimensions to identify scavengers. J. Forensic Sci. 60 (6), 1426-1435. 